\title{
A new Sesleria juncifolia association from south-eastern Italy and its position in the amphi-Adriatic biogeographical context
}

\author{
Romeo Di Pietro ${ }^{1 *}$, Robert P. WAgenSOMMER ${ }^{2}$ \\ ${ }^{1}$ Department of Planning Design Technology Architecture, Section of Landscape and \\ the Environment, Sapienza University of Rome, Via Flaminia 72, I-00198 Rome, Italy \\ 2 Viale Aldo Moro 39, I-71013 San Giovanni Rotondo (FG), Italy
}

\begin{abstract}
The Sesleria juncifolia calcareous grasslands in the Apulia region (southern Italy) were studied on the basis of 24 phytosociological relevés. According to UPGMA cluster analysis division and NMDS ordination the relevés were classified into four major groups which gave rise to three sub-associations (Gargano) and a geographically impoverished variant (Alta Murgia). The new association Stipo austroitalicae-Seslerietum juncifoliae ass. nova was proposed. Due to the relict and scattered distribution of Sesleria juncifolia in Apulia region, the variances in species composition amongst the different subassociations are mainly influenced by local factors. The community Stipo-Seslerietum should be included in the south-eastern Italian alliance Hippocrepido-Stipion austroitalicae while at the rank of order it exhibits intermediate coenological features between the Central-South Apennine endemic suborder Festuco-Seslerienalia nitidae and the North-West Balkan order Scorzonero-Chrysopogonetalia.
\end{abstract}

Key words: Apulia, Balkans, biogeography, grassland, Italy, phytosociology, Sesleria juncifolia, syntaxonomy, vegetation

\section{Introduction}

The genus Sesleria is one of the most important South-Eastern European grass groups, especially in the mountain areas where Sesleria species often play a dominant role. Of all the various taxa belonging to this genus, the Sesleria juncifolia complex is restricted to southern Europe, where it exhibits a typically amphi-Adriatic disjunct range (Fig. 1a) composed of two different sub-units: the western Balkans (from the Italian Karst to the southern Albania) and the Apennines (from the northern Tuscany to the northern Calabria). The taxonomical debate about the overall number of taxa belonging to the Sesleria juncifolia complex has always been a critical issue (see DEYL 1946, 1980; UjHELYi 1959; STRGAR 1981; Ubaldi 2006;

* Corresponding author, e-mail: romeo.dipietro@uniroma1.it

Copyright ${ }^{\circledR} 2014$ by Acta Botanica Croatica, the Faculty of Science, University of Zagreb. All rights reserved. 


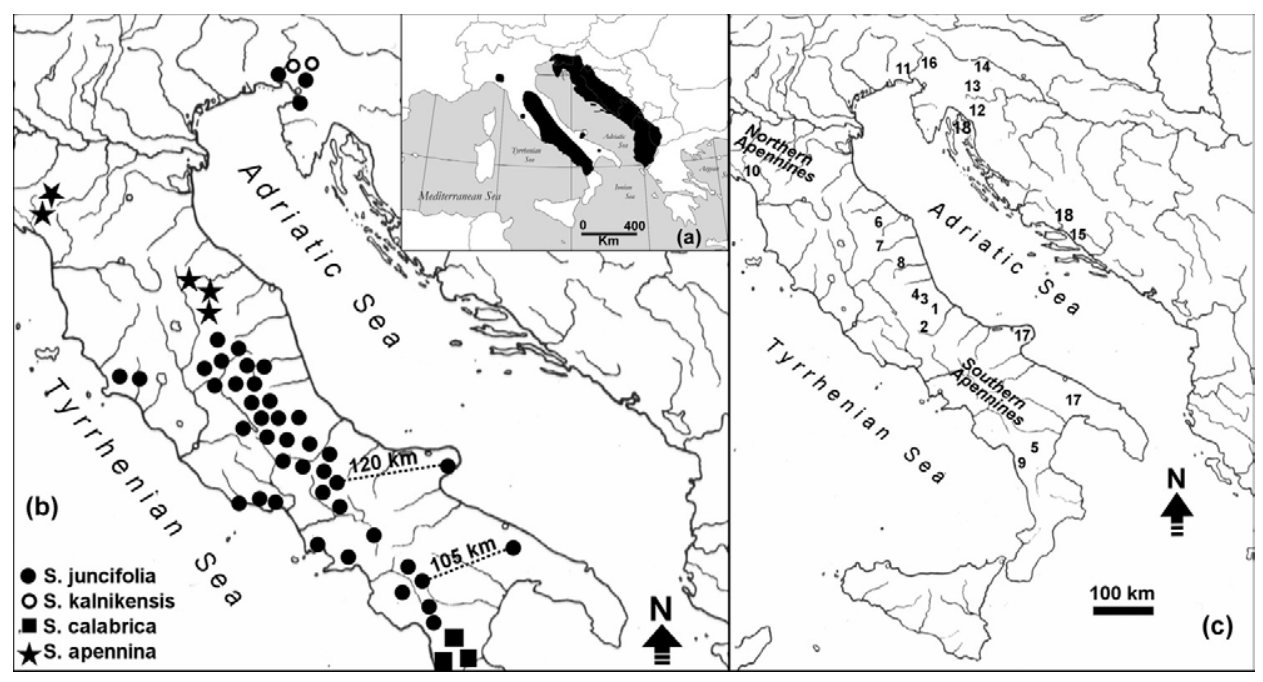

Fig. 1. Amphi-Adriatic distribution of the Sesleria juncifolia complex (a). Distributional map of the populations of $S$. juncifolia occurring within the Italian Peninsula showing the isolation of the Apulian populations from the sourrounding S. juncifolia sites (b). Geographical location of the Sesleria juncifolia s.l. associations included in the synoptic table (c).

ALEGRO 2007) that has still not been completely resolved. As far as the Italian peninsula is concerned, the occurrence of four distinct taxa (S. juncifolia Suffren, S. kalnikensis Jáv., S. apennina Ujhelyi, S. calabrica (Deyl) Di Pietro) has been recently hypothesised on the basis of karyological, morphological and biogeographical features (DI PIETRO et al. 2005, DI PIETRO 2007). Likewise all the other species belonging to the same complex, Sesleria juncifolia is a montane species having its synecological optimum in the upper montane and subalpine belts of the major central-southern Apennines limestone massifs where it is the guide species in several types of dry grasslands (BRUNO and FuRNARI 1966, PETRICCIONE and Persia 1995, Biondi et al. 1999, Blasi et al. 2005, Costanzo et al. 2009, Di Pietro 2010). Furthermore the wide ecological amplitude of this species allows it to give rise to grassland communities not only in the lower montane belt, as is the case of Carici macrolepidis-Seslerietum of Mount Cucco (BIONDI et al. 2004) and Seslerio-Stipetum appenninicolae of Sibillini mountains (CATORCI et al. 2007), but in the hilly belt too, as is the case with Genisto-Seslerietum juncifoliae in the Rosandra valley in the Friuli Venezia-Giulia region and adjacent Slovenia (Poldini 1980, KALIGARIČ 1994) and in the Rossa Gorges and Furlo Gorges in the Marches region (BRILli-CATTARINI 1972). Scattered residual populations of Sesleria juncifolia are even found on the coastal and sub-coastal cliffs of Capri island, Circeo Promontory and Mount Leano (Tyrrhenian side of the Italian peninsula) at about 300 $\mathrm{m}$ a.s.l. under typical Thermo-Mediterranean bioclimatic conditions. This wide coenological and altitudinal pattern of the Sesleria juncifolia s.l. grasslands is comparable to that occurring in the western Balkans for both the high and for the low altitude zones (Krk and Pag islands) (HoRvaT et al. 1974, REDZIC 1999).

According to PignatTi (1982) the presence of Sesleria juncifolia in Apulia region was restricted to the Gargano Peninsula, where it was known for Monte degli Angeli, Monte 
Sant'Angelo, Monte Calvo and Pulsano (FEnAroli 1974). Subsequently this species was found in other sites of the Gargano area (WAgensommer and Di Pietro 2006, WAGENSOMMER 2010) and in few isolated sites in Alta Murgia National Park (Fig. 6). These new records have resulted in $S$. juncifolia being removed from the list of endangered species at a regional level. Nevertheless, according to the subcriteria B1 $\left(100 \mathrm{~km}^{2}<\mathrm{EOO}<5,000 \mathrm{~km}^{2}\right)$ and B2 $\left(10 \mathrm{~km}^{2}<\mathrm{AOO}<500 \mathrm{~km}^{2}\right)$ and to the option $» \mathrm{a} \ll$ (7 locations in the whole region) of the IUCN rules (IUCN, 2006), in the Apulia region Sesleria juncifolia is to be considered as a species at risk of becoming »endangered « (according to the IUCN »B « criterion $S$. juncifolia is: NT B1+2ab iii).

During field research into the ecology and conservation of the rare species of Gargano National Park (Di PieTro and Wagensommer 2008), several dry grasslands communities dominated by $S$. juncifolia were found (green squares in Fig. 2). In the present research some new S. juncifolia communities stands were also identified (the red squares in Fig. 2). Because the occurrence of these Sesleria juncifolia communities was unknown to Italian botanists, no phytosociological data were available on this topic in Italian botanical literature. The presence of $S$. juncifolia communities in Apulia is a very peculiar fact, especially considering the prominent role of the Mediterranean climate in the region, the low altitudes of the main Apulian ranges (Mount Cornacchia, 1,151 m, is the highest regional peak) and their isolation from the other mountainous massifs of the Apennines. In fact the Gargano and Alta Murgia S. juncifolia communities are those that exhibit the longest distance as the crow flies from the nearest other S. juncifolia population occurring in Peninsular Italy (Fig. 1b). The geographical isolation of Gargano and Alta Murgia areas sums up to the lithological and ecological isolation of these areas which is due to the occurrence of large silty-clayey plains which surround the Gargano and Alta Murgia limestone systems. The aim of the present paper is to provide a phytosociological description of the Apulian Sesleria juncifolia communities and to make a floristic, coenological and syntaxonomical comparison with the similar Sesleria juncifolia communities described so far for the Italian and the Balkan peninsulas.

\section{Study area}

The study area is divided into two parts: Gargano promontory and Alta Murgia plateau (Fig. 2B). The promontory of Gargano, known as the »spur « of the Italian peninsula, is a succession of broad plains and low-lying hills jutting into the Adriatic Sea from the east coast of Italy, in Foggia province. It is $65 \mathrm{~km}$ long and $40 \mathrm{~km}$ at its widest, with an area of about 2,100 square $\mathrm{km}$ and it acts as an island emerging from the Tavoliere plain. Mount Gargano is composed entirely of limestone, surrounded by terraces of various geologic periods. The highest peak is Mount Calvo $(1,065 \mathrm{~m})$, while the only other peaks exceeding one thousand meters are Montenero (1,014 m) and Mount Spigno (1,008 m). The intense karst activity affecting the limestone bedrock leads to the superficial water drainage being restricted to torrential rivers, while the coastal lakes (Lesina, and Varano) in the north-western side of the promontory are very important. According to BLASI (2003) the Apulian Sesleria juncifolia sites are included in the following phytoclimatic units: Dry Meso-Mediterranean; Subhumid Meso-Mediterranean; Humid/Subhumid Mesotemperate (Fig. 2A). The potential vegetation of Gargano is almost completely composed of oak woodlands 
Di Pietro R., Wagensommer R. P.
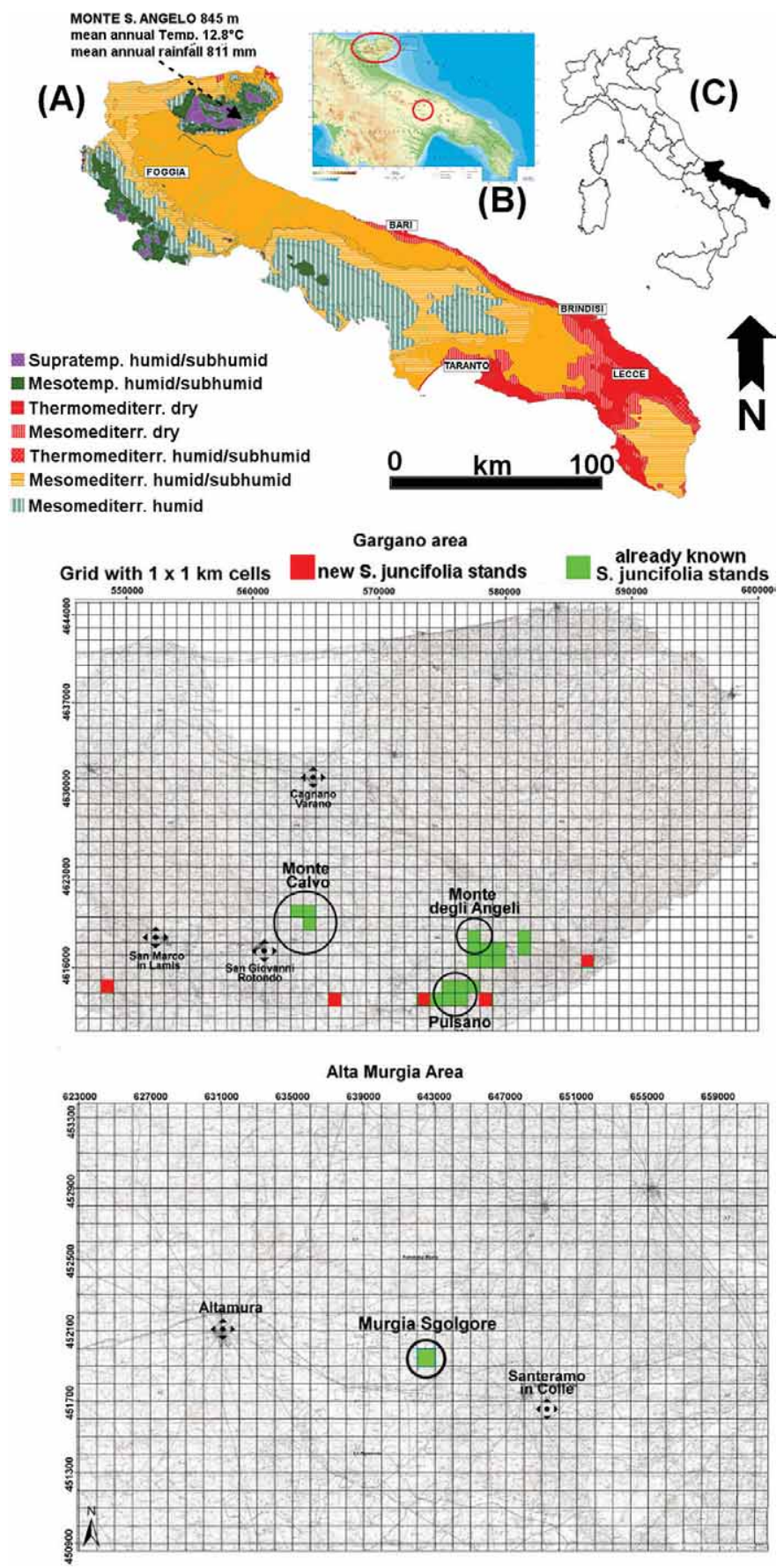

Fig. 2. Upper part: A - Bioclimatic map of Apulia region (modified after BLASI 2003) B - Apulia region physical map with the areas including Sesleria juncifolia population circled in red. CApulia region in the Italian political map. Lower part: $1 \mathrm{~km} \times 1 \mathrm{~km}$ grid of distribution of Sesleria juncifolia stands in the Gargano and Alta Murgia territories. 
(Quercus ilex, Q. pubescens, Q. cerris) except for the important site of »Umbra Foresta which is covered by a wide beech forest and of pine woods along the coasts. The Sesleria juncifolia communities are restricted to the southern slope of Gargano, which is characterized by the presence of deep vertical valleys (Vallone di Pulsano, Valle dell' Inferno, Valle del Surdo, etc). The Alta Murgian relief is a wide limestone plateau included in the territory of Bari and Barletta-Andria-Trani provinces and it is the core of the Alta Murgia National Park, which covers an area of about 680 square kilometres. The bedrock is formed by Cretaceous limestone usually covered with Pleistocene calcarenite and this geological character has determined a lot of karstic phenomena represented by swallow holes, dolinas, poljes. The highest peaks are Torre Disperata $(686 \mathrm{~m})$ and Mount Caccia $(680 \mathrm{~m})$. The deep changes caused by the human action have shaped the physiognomy of the original vegetation to the extent that it is impossible or very difficult to carry out a precise and certain analysis of the potentialities of this territory. At present the Alta Murgia Park is marked by very extended steppe-like grasslands which in the 92/43/EEC Directive are for the most included in the prior Habitat $62 \mathrm{~A} 0$ (Eastern sub-mediterranean dry grasslands), and for a minor part in the other prior Habitats 6220 and 6210.

\section{Materials and methods}

The study was carried out via a phytosociological and statistical analysis of relevés of dry grasslands with the dominance of Sesleria juncifolia performed in Apulia region (south-eastern Italy). Subsequently a phytogeographical and phytosociological comparison with the literature data regarding the Sesleria juncifolia communities of the rest of Italy and of the western Balkan Peninsula was provided. Twenty-four relevés, according to the BRAUN-BLANQUET (1964) approach, were performed in May 2007-2009. All the cover data were recorded according to the Braun-Blanquet scale and transformed into the scale proposed by VAN DER MAAREL (1979) and NOEST et al. (1989). A matrix of 24 relevés $\times 148$ species was subjected to a divisive hierarchical classification (using the chord distance algorithm to produce the dissimilarity matrix and the minimum variance linkage as agglomeration criterion on quantitative data) and to NMDS ordination (Syn-tax 2000 package, PoDANI 2001). Four main types of vegetation were distinguished from a coenological point of view and a syntaxonomical assignment was subsequently proposed. Moreover a synoptic table composed of the frequency columns of all Sesleria juncifolia s.l. associations described in Italy and in the western Balkans (On-line supplement appendix 4; Fig. 1c) was prepared and subsequently subjected to cluster analysis using the same statistical procedures mentioned above. In order to attenuate the influence of the high cover/abundance values of the grasslands' guide species, in the cluster analysis procedures the various taxa belonging to the Sesleria juncifolia complex were reported under the single collective name of S. juncifolia s.l. Owing to the thermophilous character of the Apulian communities, comparison with the Balkan Sesleria juncifolia communities was restricted to those associations which showed similar ecological features. On the contrary the S. juncifolia communities belonging to the Elyno-Seslerietea class and occurring in the subalpine and alpine belts of the Balkans were not included in this comparative cluster analysis. For the identification of plant taxa the diagnostic key published in Licht (2008) was used. The nomenclature of the taxa follows Conti et al. (2005) and Euro+Med PlantBase, whilst life form and chorotype systems follow PIGNATTI (1982). Life form and chorological analyses consider whether a particular species 
occurs or not in a cluster (normal values), its frequency (frequency values), and its cover values (cover). The physiognomical role of each species was investigated by calculating its specific cover index (BRAUN-BLANQUET 1964). In naming the phytosociological syntaxa, we adhered to the rules contained in the third edition of the International Code of Phytosociological Nomenclature (ICPN) (WEBER et al. 2000).

\section{Results}

\section{Phytosociological relevés}

The dendrogram resulting from the hierarchical classification (Fig. 3) highlighted two main clusters: cluster »A« included the $S$. juncifolia communities of Gargano promontory, while cluster $» \mathrm{~B}$ « included the residual impoverished Sesleria juncifolia communities of the Alta Murgia area. Cluster $\gg \mathrm{A} «$ is subdivided into two further subclusters. Subcl. $\mathrm{A}_{2}$ includes the Sesleria grasslands occurring within the steep slopes of the Pulsano gorge. Subcl. $A_{1}$ includes the Sesleria grasslands placed at higher altitude. In particular, cluster $\mathrm{A}_{1-1}$ includes the grasslands of the top of Mount Calvo while cluster $\mathrm{A}_{1-2}$ is related to the summit area of Mount S. Angelo. The result of the cluster analysis was confirmed by the NMDS ordination (Fig. 4), although no any correlation between axis and environmental parameters was identified.

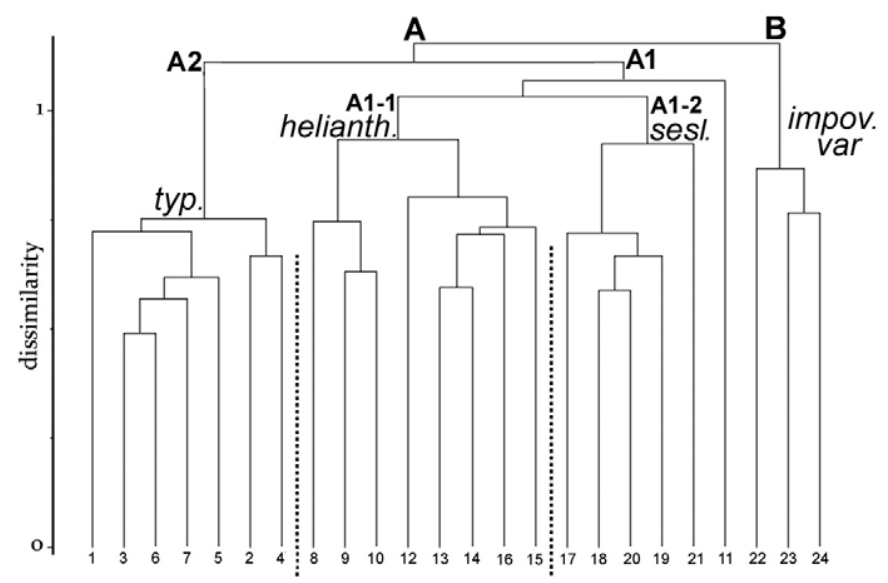

Fig. 3. Cluster analysis dendrogram of the Apulian Sesleria juncifolia communities relevés.

The geographical isolation from the rest of the Sesleria juncifolia communities occurring in the Apennines and in the Balkans have resulted in the Apulian Sesleria juncifolia dry grasslands developing very peculiar floristic and coenological features for which none of the syntaxa already published is suitable at present. For this reason we propose the new association:

Stipo austroitalicae-Seslerietum juncifoliae Di Pietro et Wagensommer ass. nov hoc loco

Holotypus: Table 1, rel. 2. For locations and dates of relevés in Tab. 1, see On-line supplement appendix 1; sporadic species are listed in the Online supplement appendix 2. 


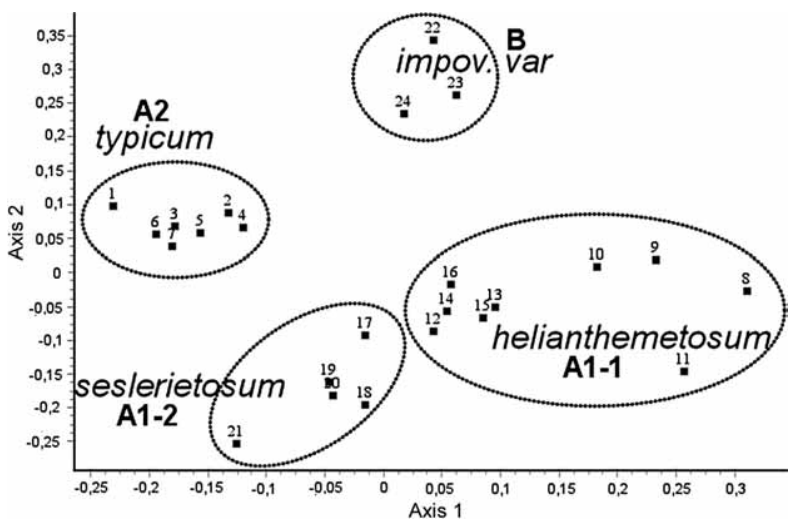

Fig. 4. NMDS Ordination of the Apulian Sesleria juncifolia communities relevés with the partition of the clusters identified by the cluster analysis.

Diagnosis: Stipo austroitalicae-Seslerietum juncifoliae dry grasslands are developed on limestone outcrops, ridges and carbonate-rich talus slopes, and are strongly dominated by Sesleria juncifolia which is joined by a complex of common calcicolous stress-tolerant species such as Plantago holosteum, Pimpinella tragium, Galium corrudifolium, Koeleria splendens, Anthyllis vulneraria subsp. rubriflora and by a group of species having a very restricted distribution such as Stipa austroitalica, Leontodon apulus, Centaurea subtilis, Satureja cuneifolia, Genista michelii (etc.). The sites are characterised by nutrient-poor calcareous xeric soils (especially lithosols) and are typically exposed to extreme microclimatic conditions such as drought and high temperature amplitude. Stipo-Seslerietum occurs, in form of isolated and highly fragmented stands, at altitudes which range between 400 and $1,050 \mathrm{~m}$.

Bioclimate: Meso-Mediterranean/Meso-temperate thermotypes; lower dry/upper sub-humid umbrotype.

Characteristic species: Stipa austroitalica, Leontodon apulus, Dianthus tarentinus, Anthyllis vulneraria subsp. rubriflora.

Dynamics: Stipo-Seslerietum forms primary grasslands on the small-size talus slopes developed within Gargano southern slope gorges. On deep soils Stipo-Seslerietum behaves like a secondary stage of Ostryo-Quercetum ilicis or Cyclamino-Quercetum virgilianae at lower altitudes or Ostrya carpinifolia woods at higher altitudes.

Distribution: Stipo-Seslerietum is endemic to the Apulia region. The majority of the sites occur in the Gargano promontory while only few relic populations occur in the Alta Murgia plateau.

Stipo-Seslerietum is divided into three sub-associations: typicum (Gargano promontory southern slopes gorges); helianthemetosum apennini (top of Mount Calvo); seslerietosum autumnalis (Mount S. Angelo ridges):

\section{Stipo austroitalicae-Seslerietum juncifoliae typicum Di Pietro et Wagensommer}

subass. nov hoc loco. Holotypus: Table 1, rel. 2

The most typical aspect of Stipo-Seslerietum is found within the steep slopes of the gorges which cut across the southern side of the Gargano promontory (Fig. 5a) where small 
Di Pietro R., Wagensommer R. P.

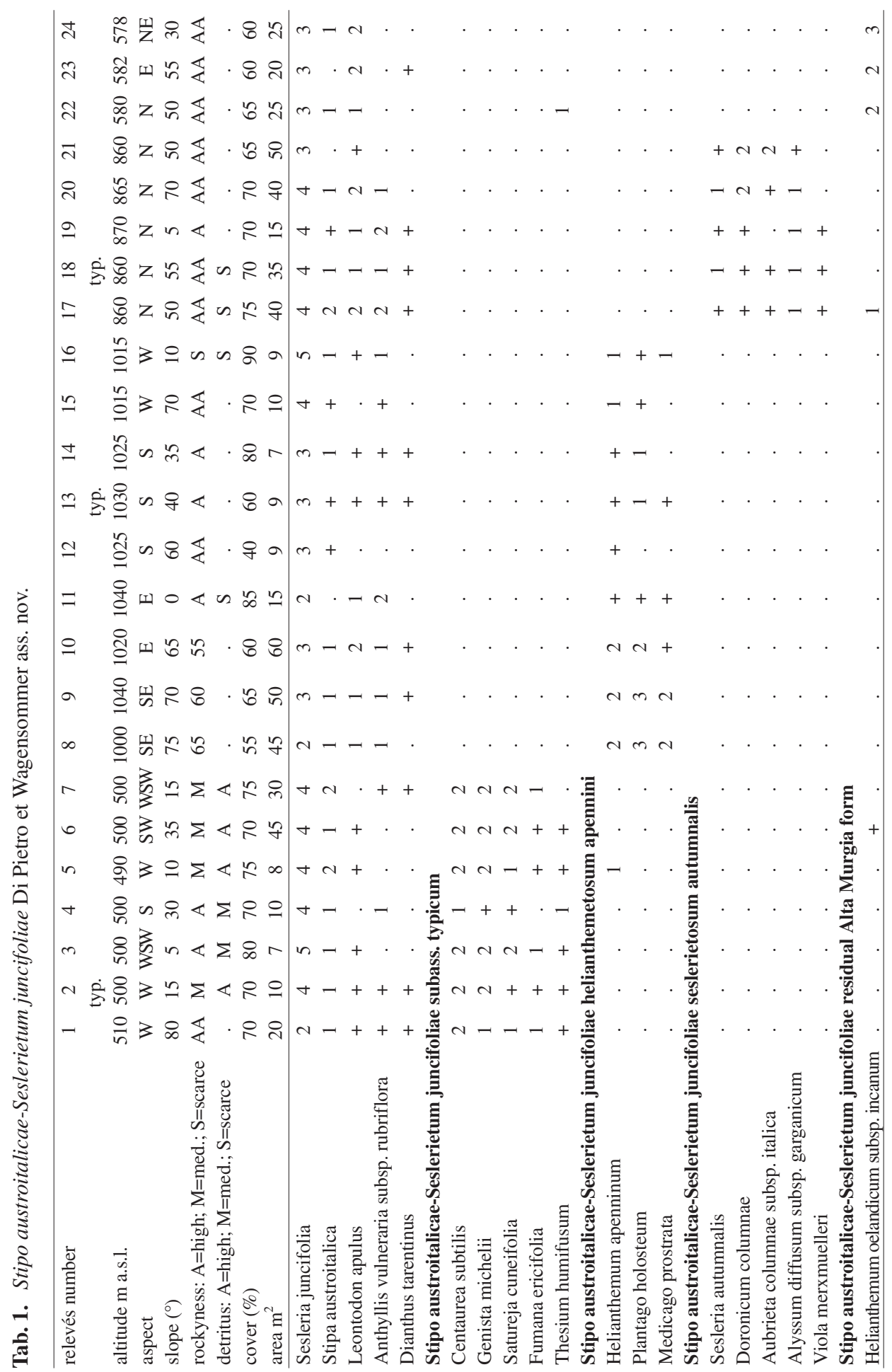




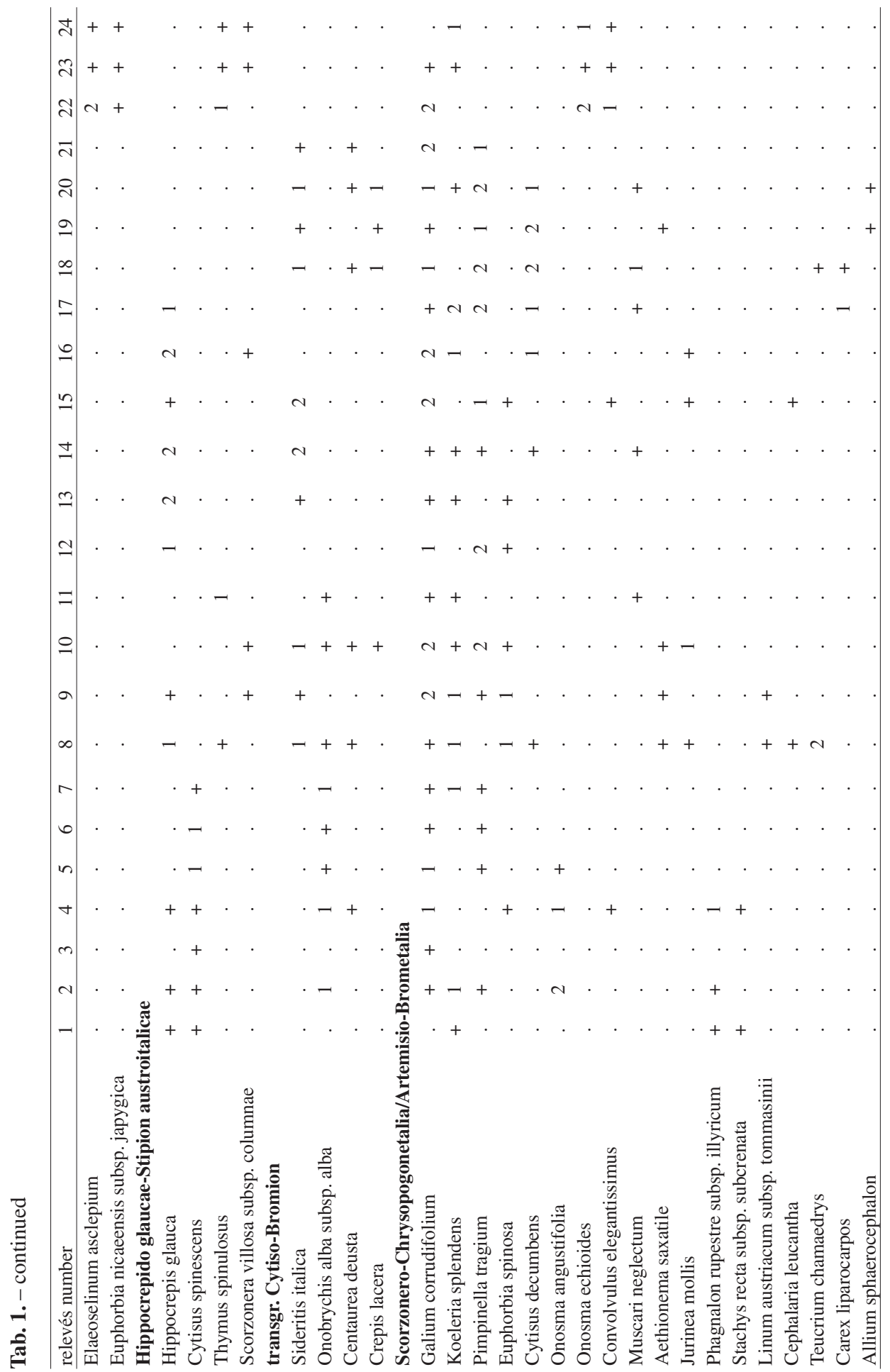


Di Pietro R., Wagensommer R. P.

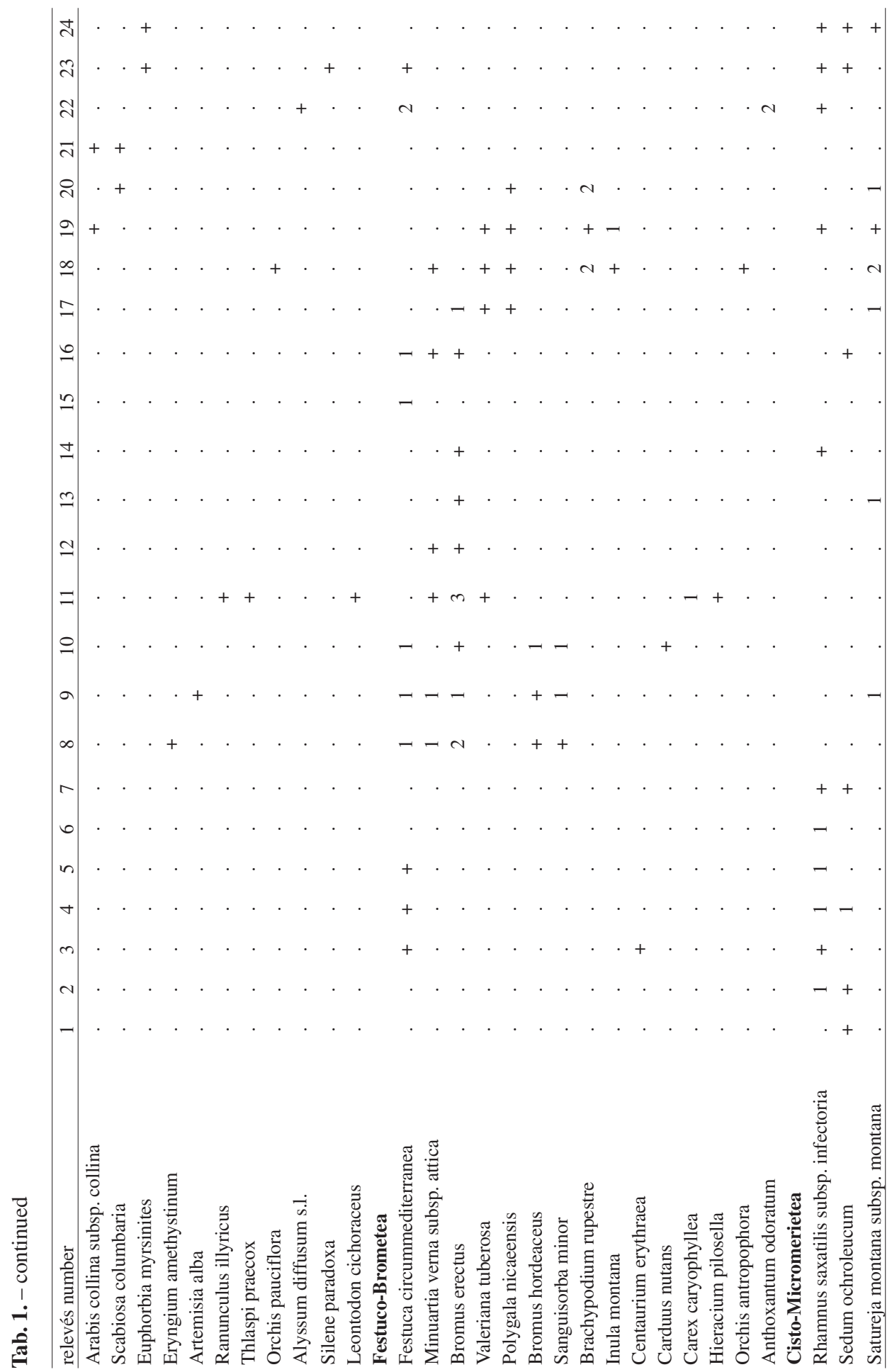




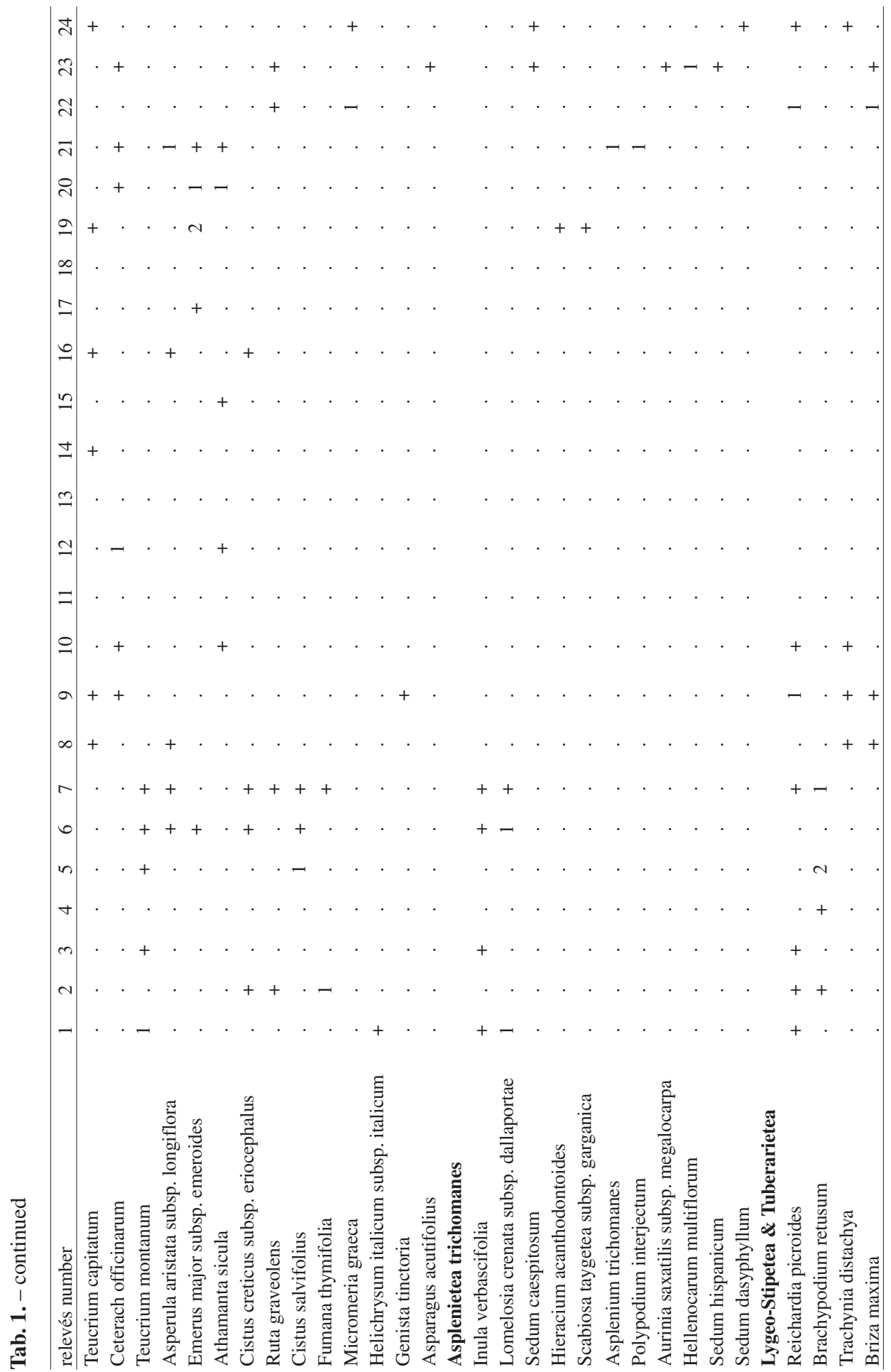


Di Pietro R., Wagensommer R. P.

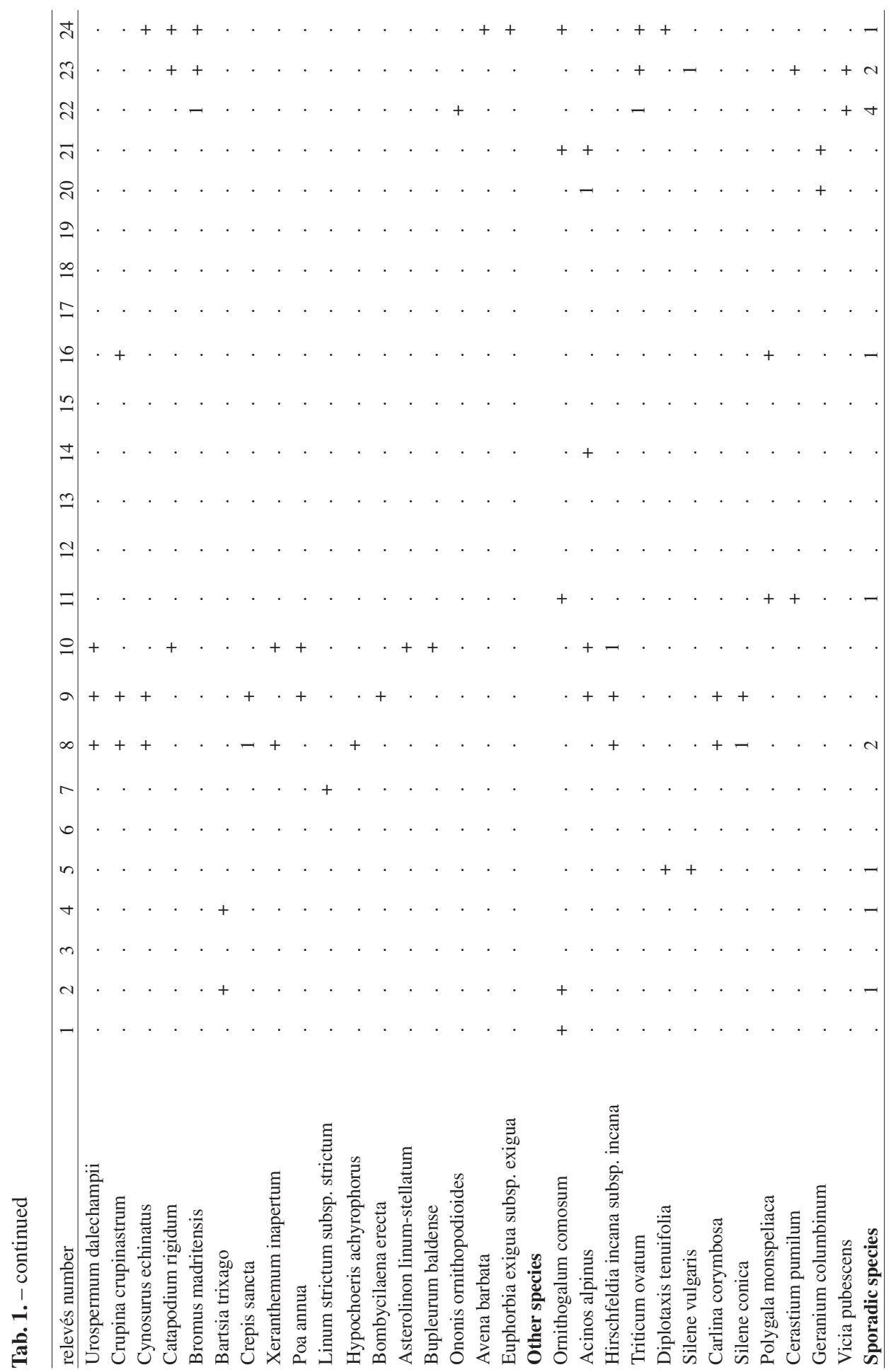


rocky outcrops emerge from a matrix composed of limestone debris. This subassociation is developed at the lowest altitude (400-520 m). The characteristic species of this subassociation are Genista michelii, Centaurea subtilis and Satureja cuneifolia, whose distribution in the Gargano area is almost only restricted to this habitat type.

\section{Stipo austroitalicae-Seslerietum juncifoliae helianthemetosum apennini Di Pietro}

et Wagensommer subass. nov hoc loco. Holotypus: Tab. 1, rel. 13

As this sub-association is restricted to the top of Mount Calvo, the highest summit of Gargano, it is the aspect of Stipo-Seslerietum which is developed at the highest altitude (exceeding $1,000 \mathrm{~m}$ ) and which best exhibits the physiognomical features of a typical dry grassland (Fig. 5b). Although it is mainly developed on rocky habitats, it can also be found on flat surfaces where Bromus erectus can play a co-dominant role together with Anthyllis vulneraria subsp. rubriflora and Plantago holosteum. The characteristic species of this sub-association are Helianthemum apenninum, Plantago holosteum and Medicago prostrata.

\section{Stipo austroitalicae-Seslerietum juncifoliae seslerietosum autumnalis Di Pietro et}

Wagensommer subass. nov hoc loco. Holotypus: Tab. 1, rel. 18

This subassociation is restricted to the north facing slopes of Monte degli Angeli (Fig. 5c) where Sesleria juncifolia become dominant in the steepest part of the slopes, at altitudes ranging between 820 and $870 \mathrm{~m}$, where a higher degree of rockiness is found. Aspects that are exclusively north-facing together with the vicinity of Ostrya carpinifolia woodlands lead to the peculiar co-existence of Sesleria juncifolia and Sesleria autumnalis which has never been recorded elsewhere in the Italian Peninsula. The characteristic species of this subassociation are Sesleria autumnalis, Doronicum columnae and Aubrieta columnae subsp. italica.
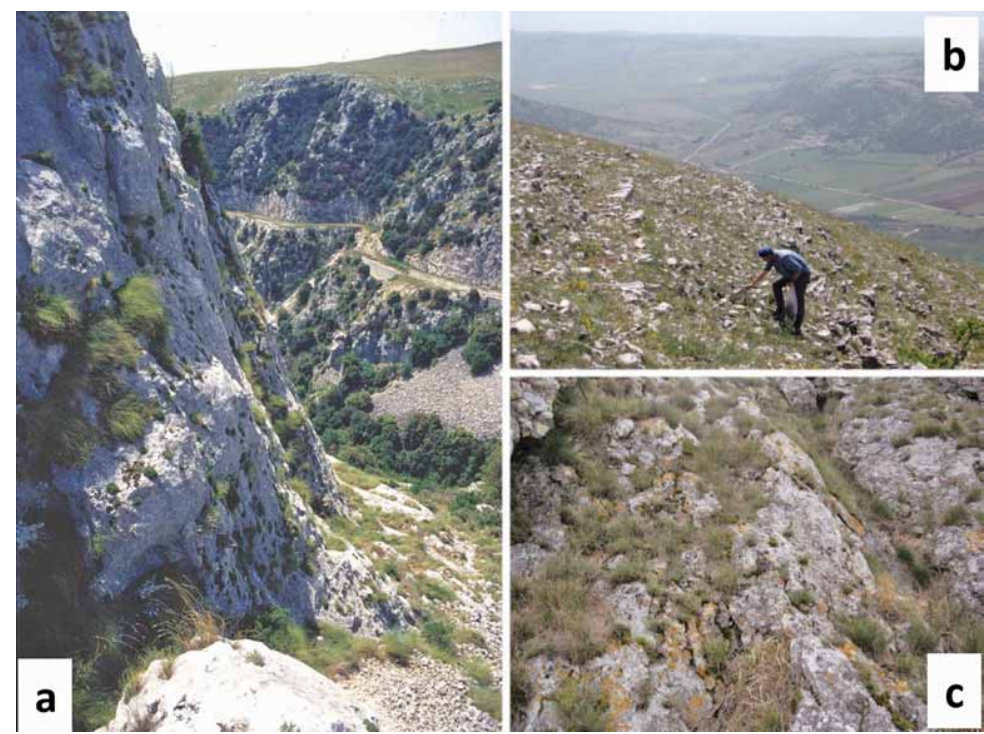

Fig. 5. Stipo-Seslerietum typicum in Pulsano valley (a), Stipo-Seslerietum helianthemetosum on the top of Mount Calvo (b), Stipo-Seslerietum seslerietosum autumnalis on the ridges of Monte degli Angeli (c). 


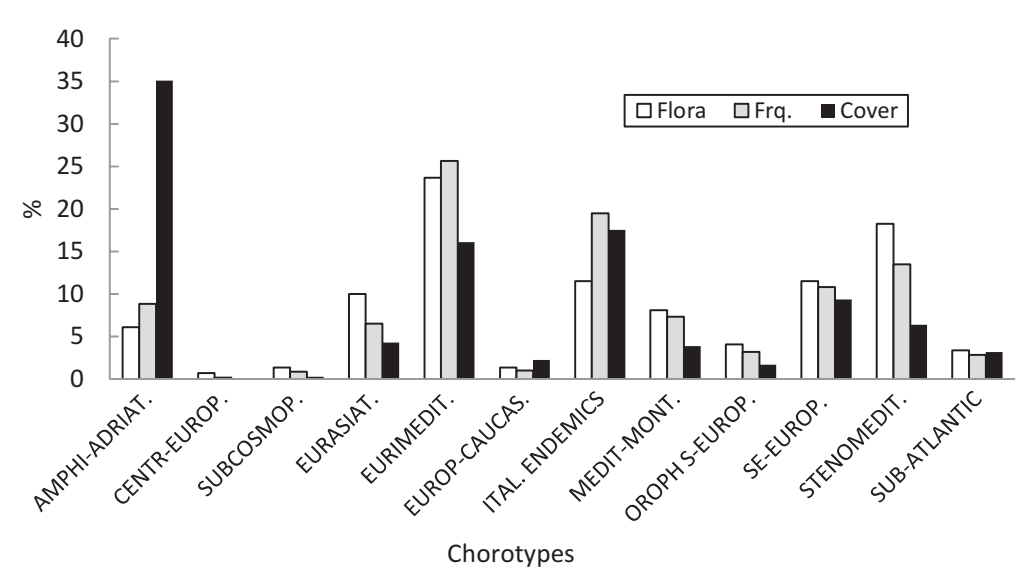

Fig. 6. Chorological spectrum of Stipo austroitalicae-Seslerietum juncifoliae calculated on the presence (Flora), frequency (Frq.), cover of a given chorotype in the phytosociological table.

Stipo austroitalicae-Seslerietum juncifoliae impoverished form

The Alta Murgia Sesleria juncifolia communities exhibit a floristic composition slightly different from that of the Gargano communities due to the presence of some endemics or amphi-Adriatic species the distribution of which is restricted to southern Apulia and the southern Balkans (e.g. Hellenocarum multiflorum, Euphorbia nicaeensis subsp. japygica). This fact, however, does not change the coenological and biogeographical features of the community as well as this does not allow the use of any other syntaxonomical references than Stipo-Seslerietum. The sporadic occurrence of Sesleria juncifolia populations in Alta Murgia restricted to a few isolated rocky outcrops has led us to classify these communities as an impoverished variant of Stipo-Seslerietum rather than as a distinct sub-association.

\section{Synoptic columns}

Sporadic species in synoptic table 4 are listed in the Online supplement appendix 3; the associations included are listed in the Online supplement appendix 4.

As far as the synoptic table is concerned, the dendrogram resulting from the hierarchical classification of the selected S. juncifolia associations (Fig. 8) highlighted two main clusters: cluster »A« which includes the $S$. juncifolia communities of the subalpine and the alpine belt of the Apennines and cluster $» \mathrm{~B}$ « which includes the associations of the hilly and the montane belt of both the Apennines and the western Balkans. Cluster B exhibits a further division in sub-cluster B1, which includes most of the Apennine and Balkan associations, and sub-cluster B2, which is restricted to two associations (the Apulian Stipo-Seslerietum and the Dalmatian Salvio-Seslerietum). A further subdivision of the subcluster B1 separates the Apennine (B1a) from the Balkan communities (B1b).

\section{Discussion}

Most of the phytosociological literature concerning the Gargano grasslands has discussed the steppe-like vegetation (especially dominated by Stipa austroitalica) of the limestone plateaus (FORTE et al. 2005, TERZI et al. 2010) or the chasmophytic communities rich 


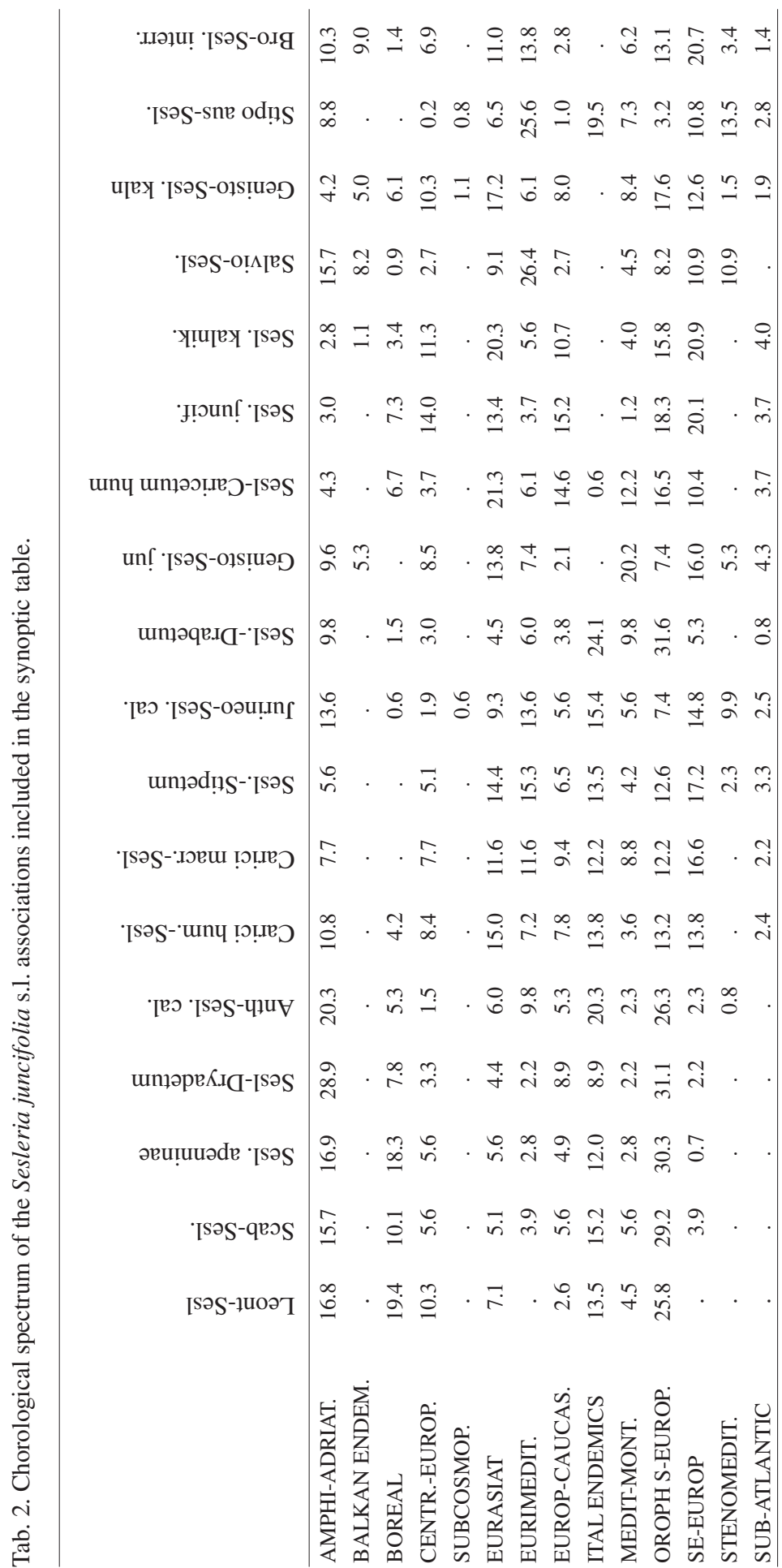


in endemic and rare species (BIANCO et al. 1988, Di PiETRO and WAGENSOMMER 2008, TerzI and D' AMICо 2008). By contrast, the grassland types developed in other habitats such as rocky slopes, stable talus slopes or mountain ridges (which are those in which S. juncifolia dominates more frequently) have been overlooked. This is why Sesleria juncifolia is known only for its role of »companion« species, as in some Centaureo-Campanuletalia chasmophitic communities, while it has never been associated with the role of guide species in a grassland community. It is not easy, however, to provide an unequivocal syntaxonomical framework for these Apulian Sesleria juncifolia communities. Although their ecological features are similar to those of the other S. juncifolia communities of the rest of the Apennines, their floristic composition is quite different. The low average altitude of the Apulian relief and the high incidence of the Mediterranean climate result in Stipo-Seslerietum being characterized by higher percentages of therophytes and a lower percentages of Boreals and south-European orophytes when compared to the Sesleria communities occurring within the true Apennines (Tabs. 2 and 3). Furthermore Stipo-Seslerietum hosts several species (e.g. Lomelosia crenata subsp. dallaportae, Centaurea subtilis, Genista michelii, Satureja cuneifolia, Inula verbascifolia, Aubrieta columnae subsp. italica etc.) which exhibit an Italian distribution more or less restricted to the Apulian region. These chorological features are due to the past and present geographical isolation of the Gargano and Murge ranges. The phytosociological literature reports that the majority of the Italian primary and secondary Sesleria juncifolia s.1. associations have been described for the montane and subalpine belts of the Apennines and are to be included in the Seslerion apenninae alliance and in the Elyno-Seslerietea class (BRuno and Furnari 1966; Biondi et al. 1988; PETRICCIONE and PERsia 1995; Biondi et al. 1999, 2004; Blasi et al. 2003, 2005). The Jurineo mollis-Seslerietum calabricae of the Pollino-Orsomarso massif (Di PIETRO 2010) and Seslerio-Stipetum appenninicolae of the Sibillini mountains (CATORCI et al. 2007) have alone been included in the Cytiso-Bromion erecti alliance (ex Phleo ambigui-Bromion erecti) and in Festuco-Brometea class. The complete lack of the subalpine endemic and southeastern European orophitic components does not allow Seslerion apenninae to be used as a good reference for the Apulian Stipo-Seslerietum. The strong occurrence of the steno-Mediterranean therophytic component mixed with a significant percentage of amphi-Adriatic hemycryptophytic and chamaephytic components suggests that other syntaxonomical references could be hypothesised (e.g.Cytiso-Bromion erecti and Hippocrepido-Stipion austroitalicae,

Tab.3. Life form spectrum of the Sesleria juncifolia s.1. associations included in the synoptic table.

\begin{tabular}{|c|c|c|c|c|c|c|c|c|c|c|c|c|c|c|c|c|c|c|}
\hline & 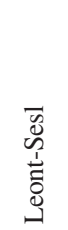 & $\begin{array}{l}\dot{\vec{D}} \\
\tilde{\omega} \\
\hat{1} \\
\hat{\tilde{J}} \\
\tilde{n}\end{array}$ & 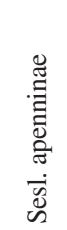 & 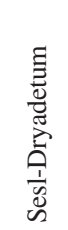 & 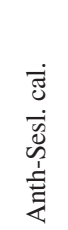 & 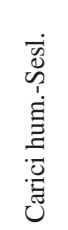 & 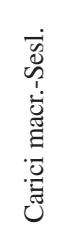 & 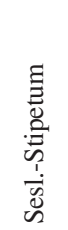 & 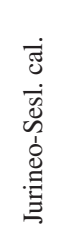 & 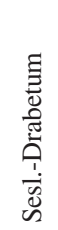 & 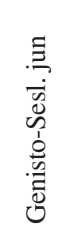 & 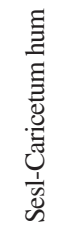 & 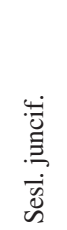 & 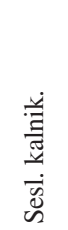 & 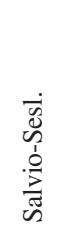 & 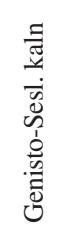 & 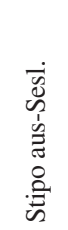 & 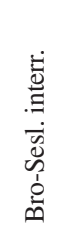 \\
\hline $\mathrm{CH}$ & 28.4 & 27.0 & 28.9 & 37.8 & 37.6 & 27.5 & 22.1 & 26.0 & 30.7 & 34.6 & 30.9 & 28.7 & 17.1 & 18.1 & 30.9 & 20.6 & 25.5 & 31.2 \\
\hline $\mathrm{G}$ & 1.9 & 3.4 & 6.3 & 3.3 & 0.8 & 6.6 & 7.2 & 6.0 & 5.5 & . & 13.8 & 5.5 & 5.5 & 10.2 & 10.0 & 6.1 & 4.2 & 4.2 \\
\hline $\mathrm{H}$ & 67.7 & 61.8 & 60.6 & 54.4 & 55.6 & 62.9 & 63.5 & 63.7 & 52.1 & 65.4 & 53.2 & 61.6 & 76.8 & 70.6 & 57.3 & 64.1 & 41.5 & 61.8 \\
\hline $\mathrm{PH}$ & 0.6 & 1.7 & 1.4 & . & 2.3 & . & 0.6 & . & 9.2 & . & 2.1 & 3.7 & . & . & . & 8.1 & 3.2 & 1.4 \\
\hline $\mathrm{T}$ & 1.3 & 6.2 & 2.8 & 4.4 & 3.8 & 3.0 & 6.6 & 4.2 & 2.5 & . & . & 0.6 & 0.6 & 1.1 & 1.8 & 1.0 & 25.6 & 1.4 \\
\hline
\end{tabular}


which are typical alliances of the lower altitudinal belts). The possible choice of Cytiso-Bromion (endemic alliance of the central and southern Italy) would be supported by the presence of the two Apennine endemics Sideritis italica and Crepis lacera and by a group of southeastern-European species (Centaurea deusta, Onobrychis alba subsp. alba and Cytisus spinescens), which various authors considered in the role of differentials for this alliance in their syntaxonomical synthesis. These same species, however, are frequently found also in the communities of the alliance Hippocrepido-Stipion austroitalicae, this latter including the steppe-like vegetation of the easternmost side of the Italian Peninsula (Apulia, eastern Basilicata and eastern Molise regions). Hippocrepido-Stipion is represented in Stipo-Seslerietum by the majority of its characteristic component (Stipa austroitalica, Thymus spinulosus, Hippocrepis glauca, and Scorzonera villosa subsp. columnae). For this reason we have preferred to include Stipo-Seslerietum in the alliance Hippocrepido-Stipion austroitalicae rather than in Cytiso-Bromion. At a higher syntaxonomical rank, the choice of Hippocrepido-Stipion would result in Stipo-Seslerietum being included in the order Scorzonero-Chrysopogonetalia the presence of which in the Italian peninsula was known for the karst territories of NE Italy (FEOLI-CHIAPELLA and POLDINI 1993) and has been subsequently recorded for the Apulia and Molise regions in southern Italy (FANELLI et al. 2001, ForTE et al. 2005, Di Pietro and Wagensommer 2008, Terzi et al. 2010). Precisely in the sub-Mediterranean zones of Friuli Venezia-Giulia Karst, PolDINI (1980) described the association Genisto sericeae-Seslerietum juncifoliae which exhibits ecological and structural features very similar to those of the Apulian Stipo-Seslerietum. Both communities are developed at relatively low altitudes, where there is a greater influence of the Mediterranean climate, and are characterized by a group of species which behave as geographical vicariants (Genista michelii / G. sylvestris, Satureja montana /S. variegata; Satureja cuneifolia / S. subspicata; Athamanta sicula / A. turbith; Centaurea subtilis / C. rupestris; Stipa austroitalica / S. eriocaulis). Dry grasslands dominated by the Stipa-Sesleria taxa association are not a novelty for the Italian Peninsula since they are known also for the central Apennines (montane belt of the Sibillini mountains in Marches region) with the community Seslerio juncifoliae-Stipetum appenninicolae (CATORCI et al. 2007). Notwithstanding their physiognomical similarities, the Apulian Stipo-Seslerietum and the Marches Seslerio-Stipetum are easily distinguishable from a floristic point of view due to the presence of a significantly higher Mediterranean component in the Apulian association (Tab. 2). The cluster analysis of the synoptic table (Fig. 8) including most of the Sesleria juncifolia s.l. associations described for both sides of the Adriatic Sea (Fig. 1c) reports the geographical location of these associations) - shows that Stipo austroitalicae-Seslerietum is clearly separated from the Sesleria juncifolia s.l. associations described for the subalpine and upper montane belts of the Italian Peninsula (Seslerion apenninae; cluster A) whereas it is included in the cluster which encompasses the central and southern Apennine Sesleria juncifolia associations belonging to the Festuco-Brometea class (cluster B). The thermophilous Sesleria juncifolia associations described for the western Balkans form a clearly-distinguishable eastern-Adriatic sub-cluster (B1b) in the Festuco-Brometea cluster, except for Salvio-Seslerietum juncifoliae of coastal Croatia which segregates together with Stipo-Seslerietum in the dendrogram. This amphi-Adriatic link between Stipo-Seslerietum and Salvio-Seslerietum, which could suggest a possible inclusion of Stipo-Seslerietum in Scorzonero-Chrysopogonetalia, is only due to the sharing of a group of thermophilous species (Cephalaria leucantha, Teucrium capitatum, Convolvulus elegantissimum, Brachypodium retusum, Helichrysum italicum etc.) that do not occur in the Sesleria juncifolia communities of the high altitude zones. By 
contrast, there are some other typical amphi-Adriatic species which can be expected on both the sides of the Adriatic Sea (e.g. Helianthemum oelandicum subsp. incanum, Festuca circummediterranea, Onosma echioides, Jurinea mollis, etc.) which curiously occur only in the Italian Sesleria juncifolia grasslands tables. The only taxon which testifies to an amphi-Adriatic connection between Stipo-Seslerietum and Salvio-Seslerietum is the chasmophitic Inula verbascifolia, which occurs in both these associations with the role of »companion $\ll$.

As mentioned before, one of the most distinctive characters of Stipo-Seslerietum is that of exhibiting a percentage of therophytes which is significantly higher than those found in the other Sesleria juncifolia associations (Tab. 3). The presence of a strong Mediterranean therophytic component, however, is also a diagnostic character of the alliance Hippocrepido-Stipion austroitalicae in comparison with other similar alliances (Cytiso-Bromion, Satureion subspicatae, Scorzonerion villosae), and this supports our decision to choose it as syntaxonomical reference. It is more complicated to identify a proper reference at the rank of order. Koeleretalia splendentis which was proposed by HoRVATIĆ (1973) for separating Mediterranean from the temperate steppe-like grasslands (Scorzoneretalia villosae) would be suitable both in physiognomical and bioclimatic terms but it was subsequently reported to Scorzonero-Chrysopogonetalia, and, for a minor part, to Cymbopogono-Brachypodietalia. Owing to the impossibility of including Stipo-Seslerietum in Cymbopogono-Brachypodietalia, or in any other Thero-Brachypodietea syntaxon (as reported in figure 7) the presence of a high number of therophytes in Stipo-Seslerietum is not accompanied by an equally important role in terms of cover percentages), the choice necessarily falls upon Scorzonero-Chrysopogonetalia, although there still are many unsolved questions concerning the coenological and syntaxonomical features of this order and many doubts on the possibility that its distribution area could be extended to the southern Italy. Several of the species identified as characteristic of Scorzonero-Chrysopogonetalia by the various authors (e.g. Horvatić 1973, 1975; Horvat et al. 1974; FeOli-Chiapella and Poldini 1993; RedžIć 1999) such as Potentilla zimmeteri, Leucanthemum atratum subsp. platylepis, Knautia illyrica, Knautia resmannii, Salvia pratensis subsp. saccardiana, Pseudolisymachion barrelieri subsp. nitens, Centaurea scabiosa subsp. fritschii, Scorzonera villosa subsp. villosa exhibit a prevailing northern Adriatic distribution and do not occur in southern Italy. At the same time other species often associated to Scorzonero-Chrysopogonetalia dry grasslands (Plantago holosteum, Polygala nicaeensis subsp. mediterranea, Cyanus triumfetti, Koeleria

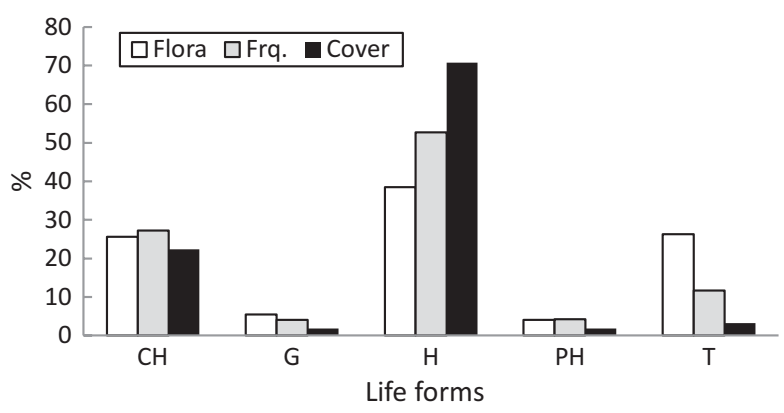

Fig. 7. Life form spectrum of Stipo austroitalicae-Seslerietum juncifoliae calculated on the presence (Flora), frequency (Frq.), cover of a given life form in the phytosociological table. 
splendens s.l., Eryngium amethystinum, Leontodon crispus, Thlaspi praecox, Thymus longicaulis, Sanguisorba minor etc.) are considered characteristic of Artemisio-Brometalia or closely related syntaxa by other authors (ROYER 1991, BiONDI et al. 1995, MucinA et al. 2009, Di PIETRo 2011). On the one hand the high presence of Italian endemic species (Fig. 6 ), most of which are endemic to the central-southern Apennine range, would clearly suggest the inclusion of Stipo-Seslerietum and Hippocrepido-Stipion in the suborder Festuco-Seslerienalia nitidae which has been recently proposed in the coenological range of Artemisio-Brometalia for central and southern Italy (Di PIETRO 2011). On the other hand the presence of several species which are endemic to the Apulian limestone platform (Centaurea subtilis, Lomelosia crenata subsp. dallaportae, Aubrieta columnae subsp. italica, Genista michelii, Viola merxmullerii, Euphorbia nicaeensis subsp. japygica etc.) and of several thermophilous southeastern European species advises against the use of a western and central-European order such as Artemisio-Brometalia.

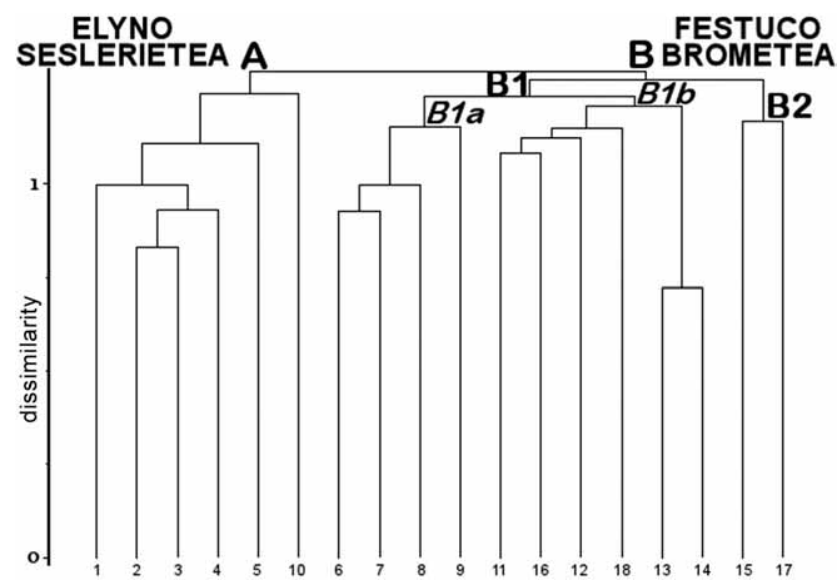

Fig. 8. Cluster analysis of the synoptic columns of the main Sesleria juncifolia associations occurring in the Italian and Balkan Peninsula (List of the associations in On-line supplement appendix 4). A - Peninsular Italy Sesleria juncifolia microthermic associations belonging to Elyno-Seslerietea class. B1a - thermophilous « Sesleria juncifolia association of the Italian Peninsula; B1b - »thermophilous « Sesleria juncifolia associations of the Dinaric and Karst territories; B2 - Stipo-Seslerietum + Salvio-Seslerietum.

\section{Conclusion}

The description of Stipo austroitalicae-Seslerietum juncifoliae is a step towards filling a gap in the phytosociological knowledge of the Apulian vegetational pattern and in defining the syntaxonomical and distributional framework of Sesleria juncifolia communities in Peninsular Italy. This association is unusual in peninsular Italy in being located at significantly lower altitudes than the other Sesleria juncifolia communities and in its Mediterranean bioclimatic context. Although several amphi-Adriatic species occur in this association the floristic similarities with the thermophilous $S$. juncifolia communities occurring in the western coastal side of the Balkan Peninsula are rather low. In syntaxonomical terms Stipo-Seslerietum has been included here in the southern Italy endemic alliance Hippo- 
Di Pietro R., WAgENSOMMER R. P.

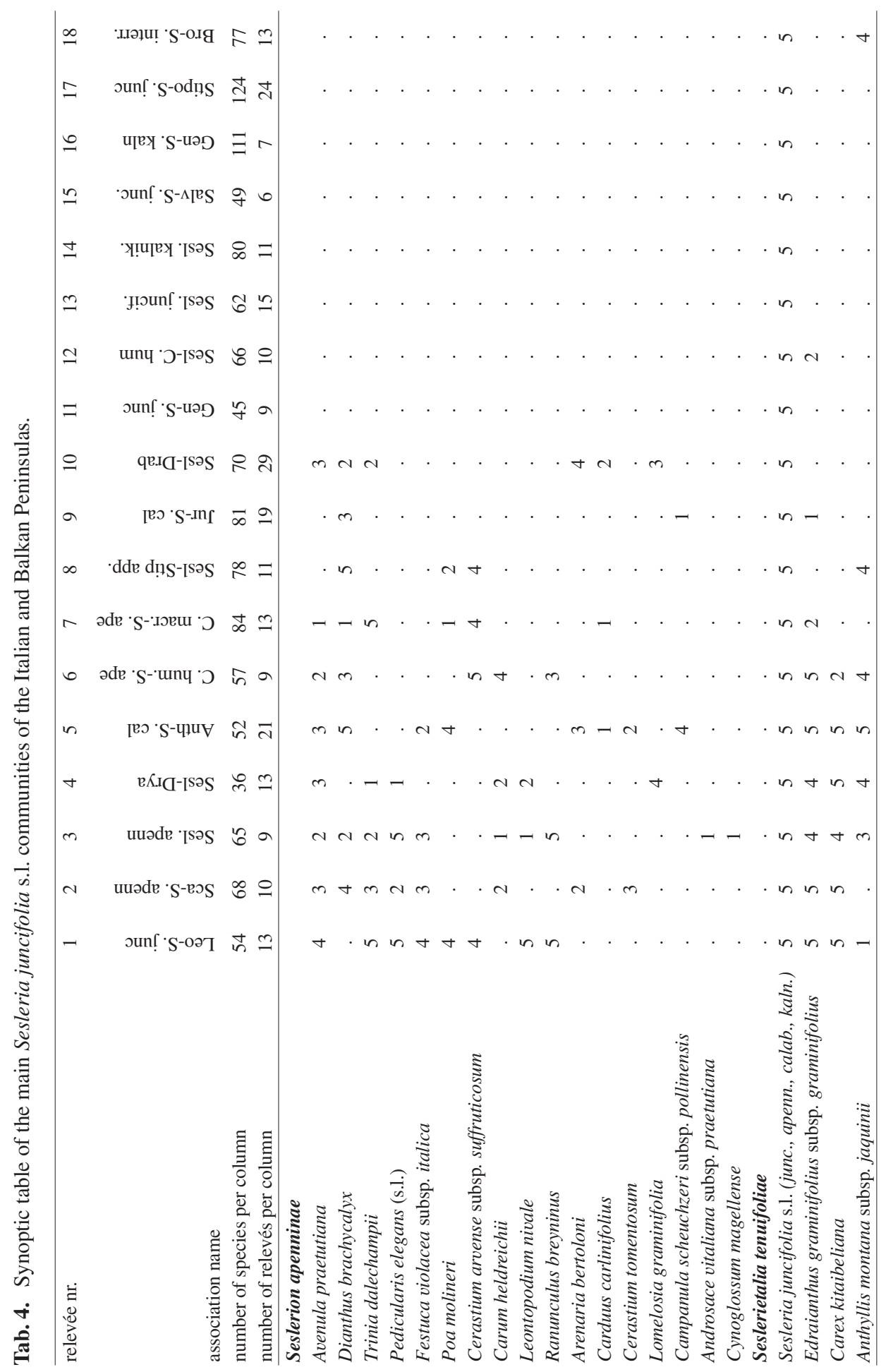




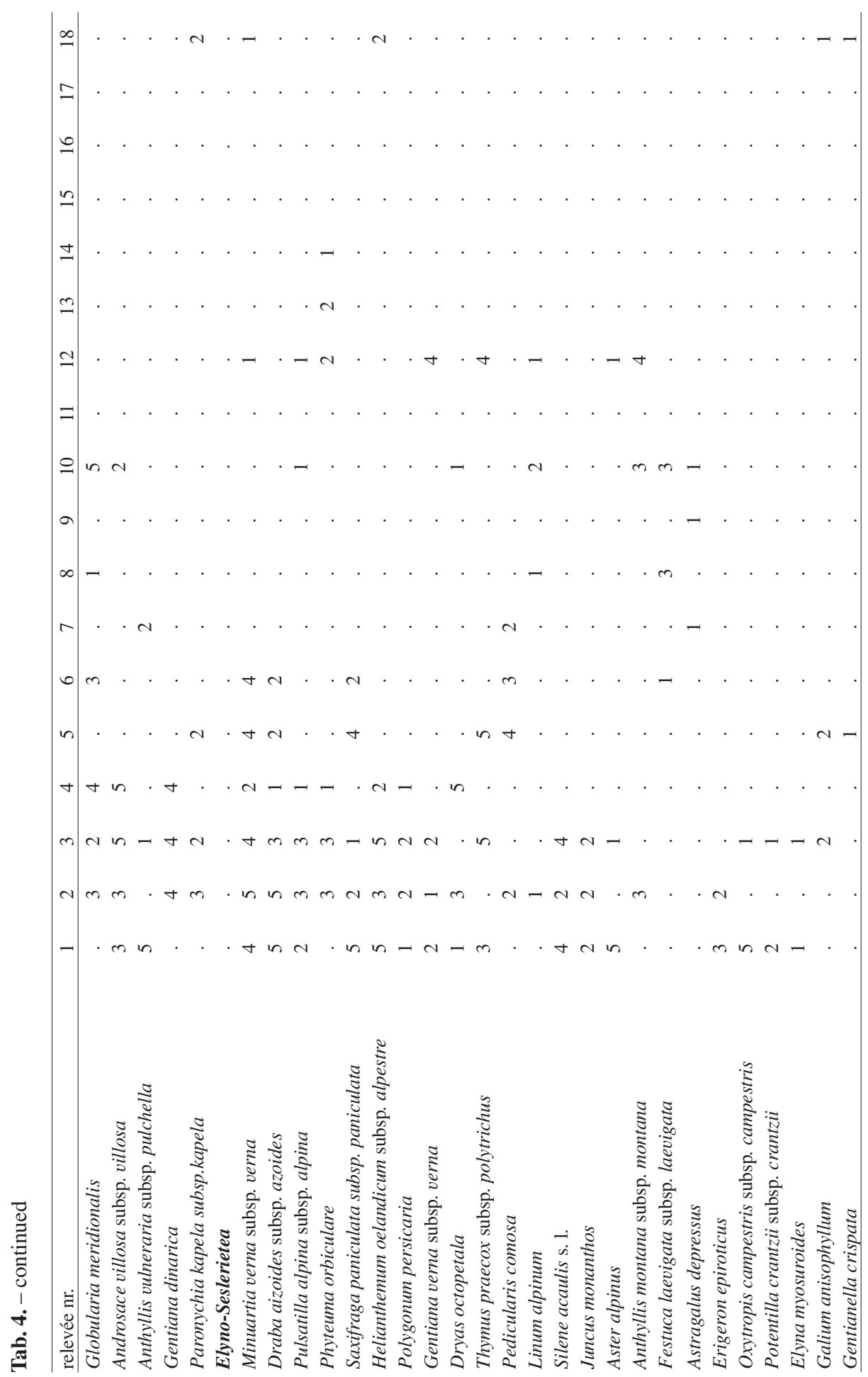


Di Pietro R., Wagensommer R. P.

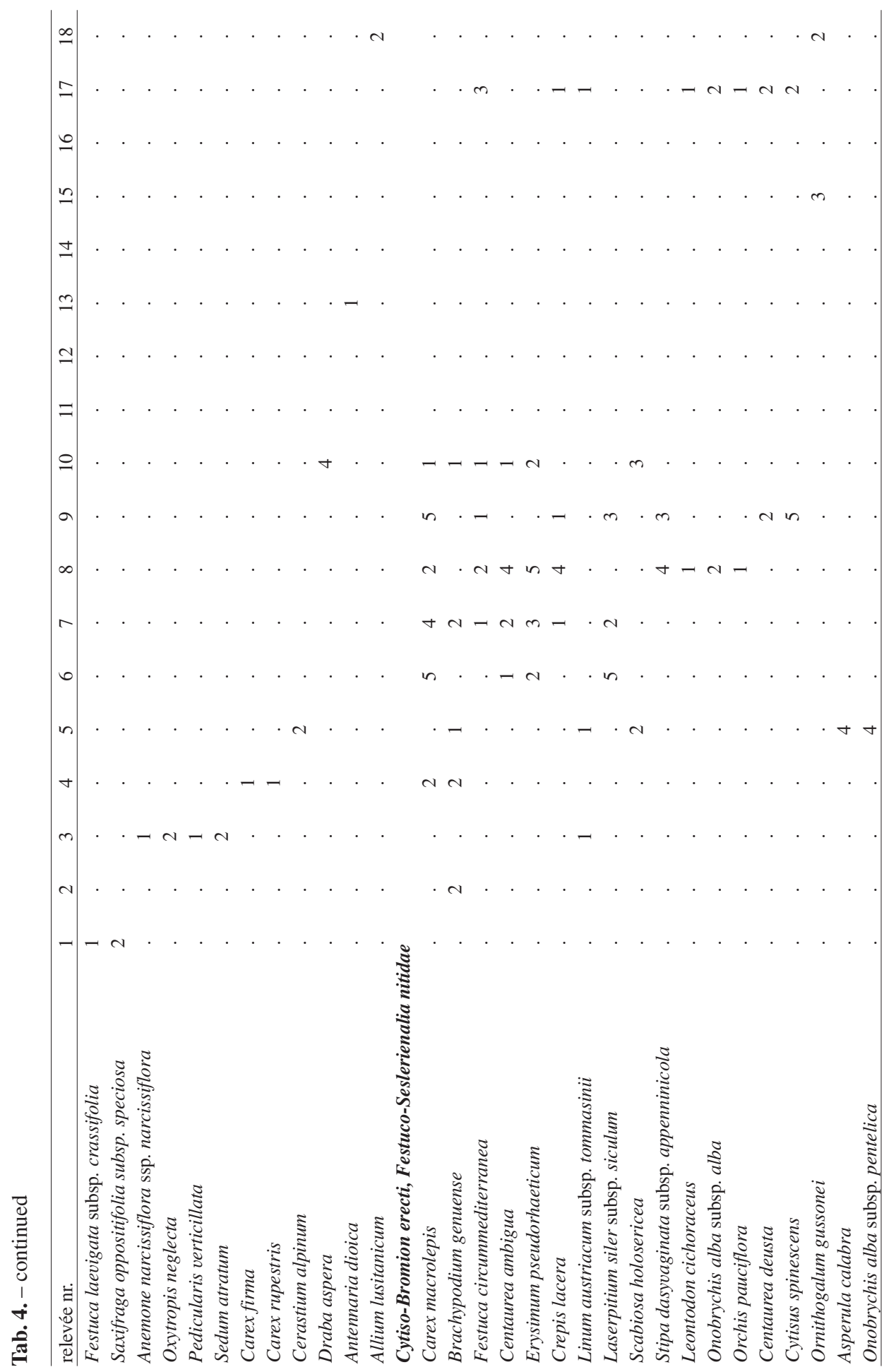




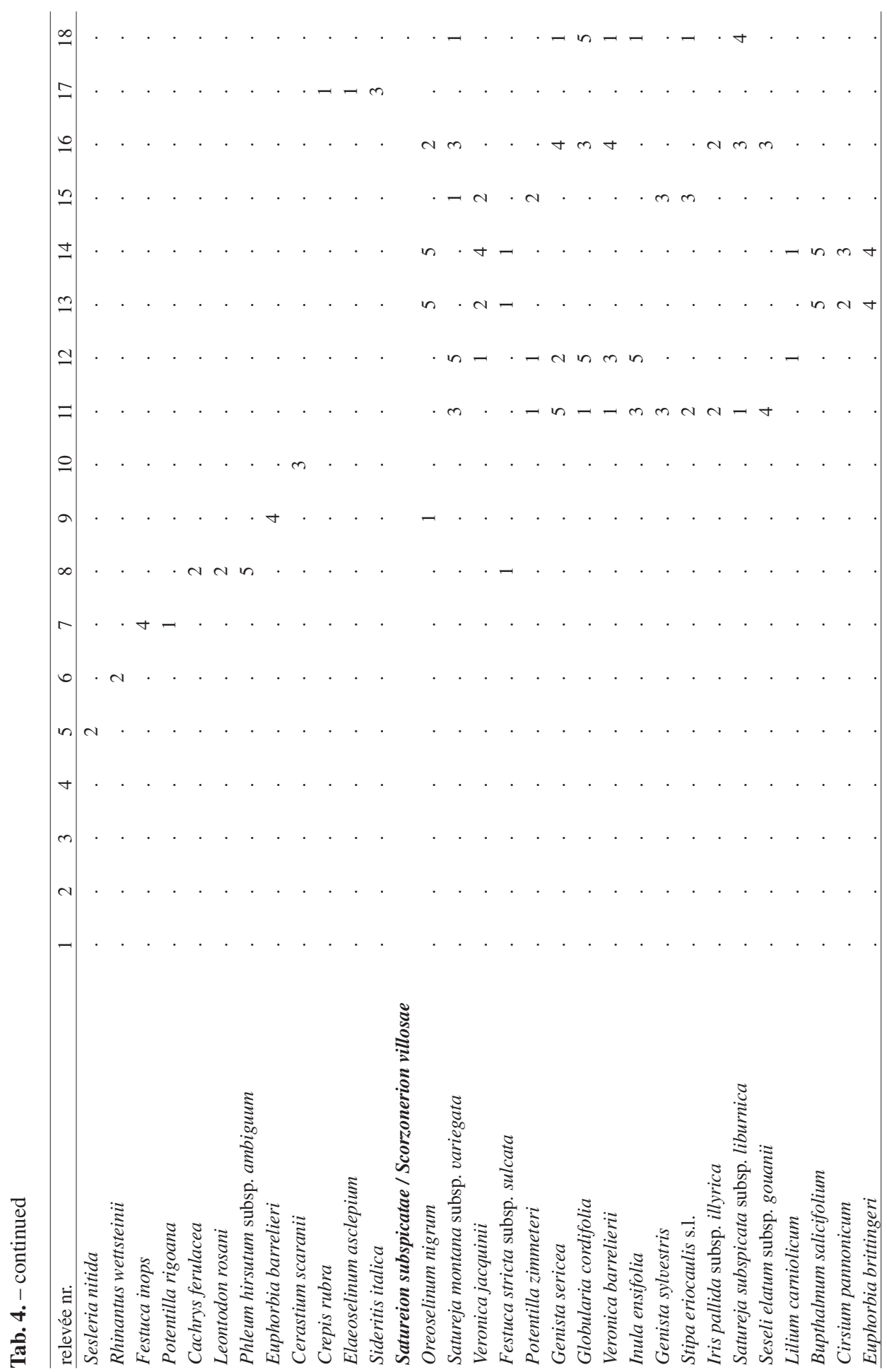


Di Pietro R., Wagensommer R. P.

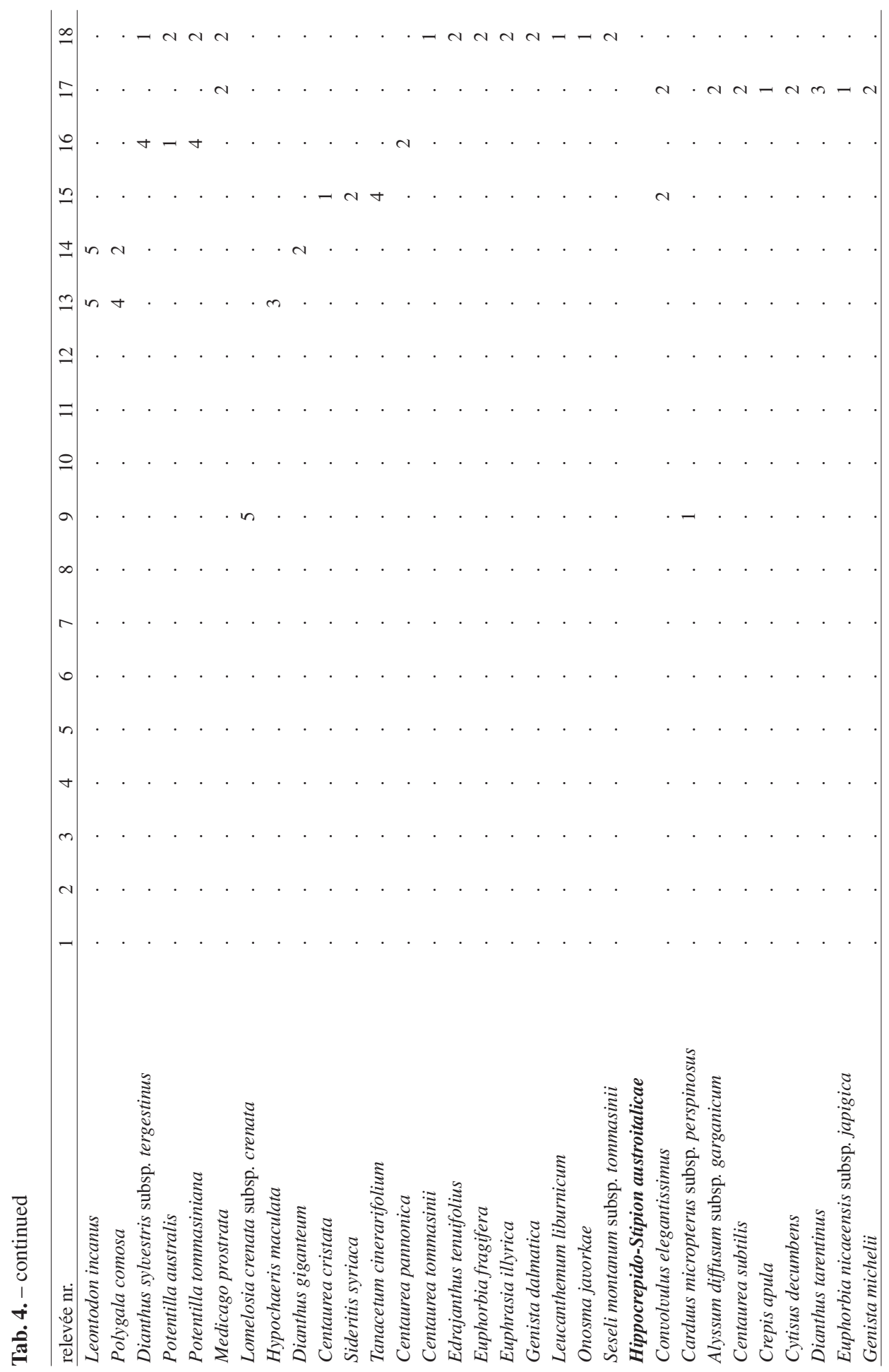




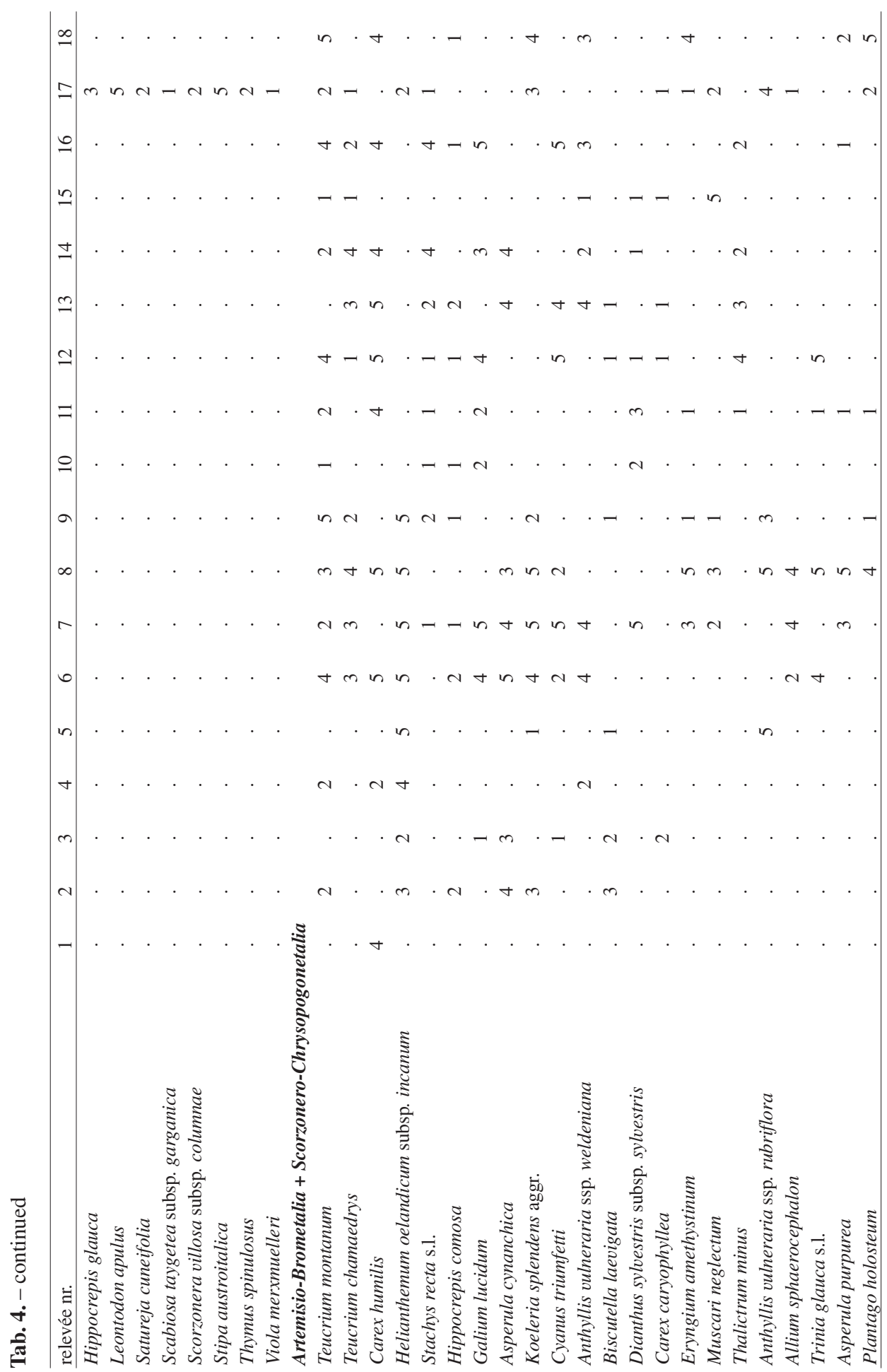


Di Pietro R., WAgENSOMMER R. P.

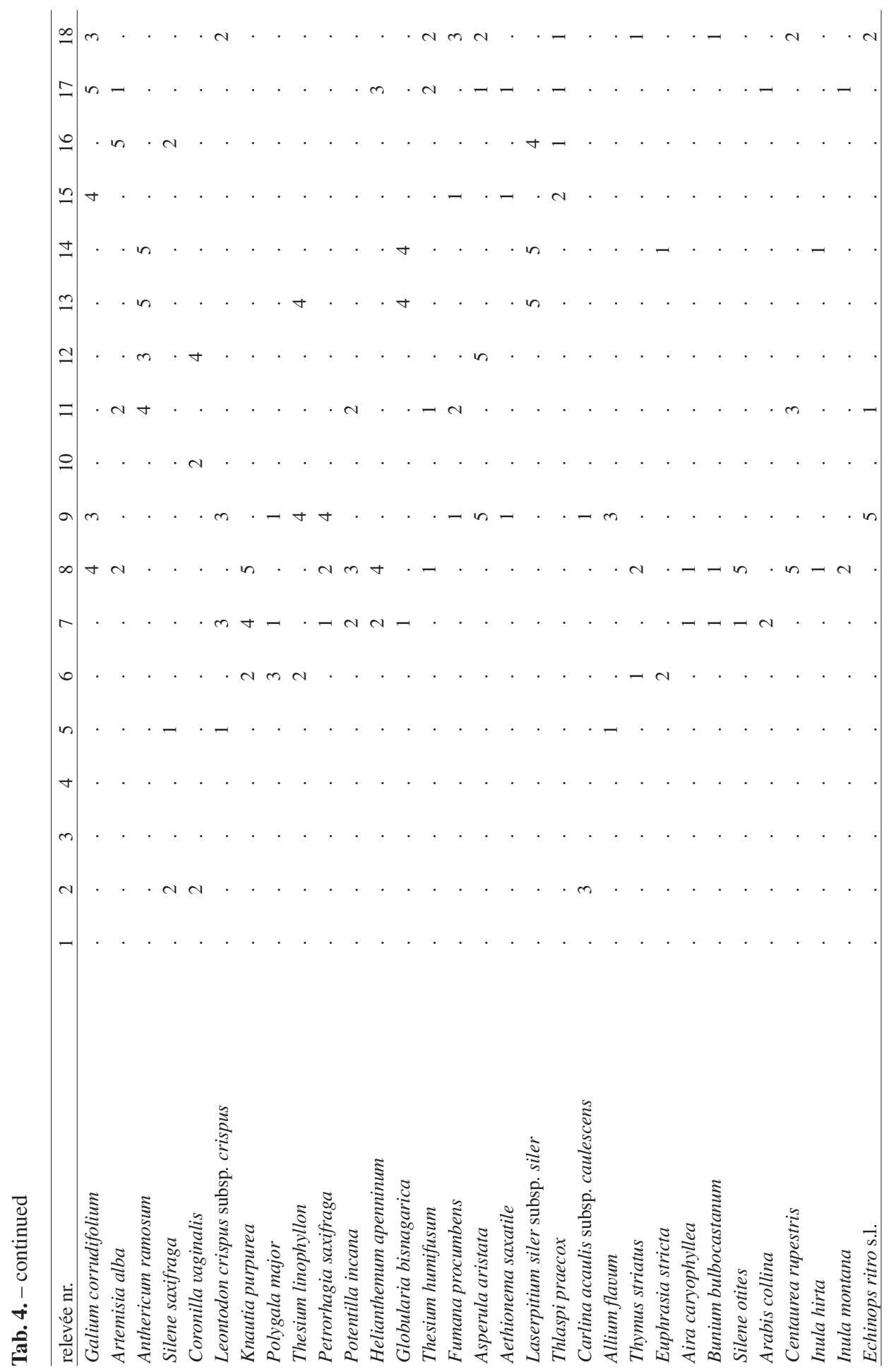




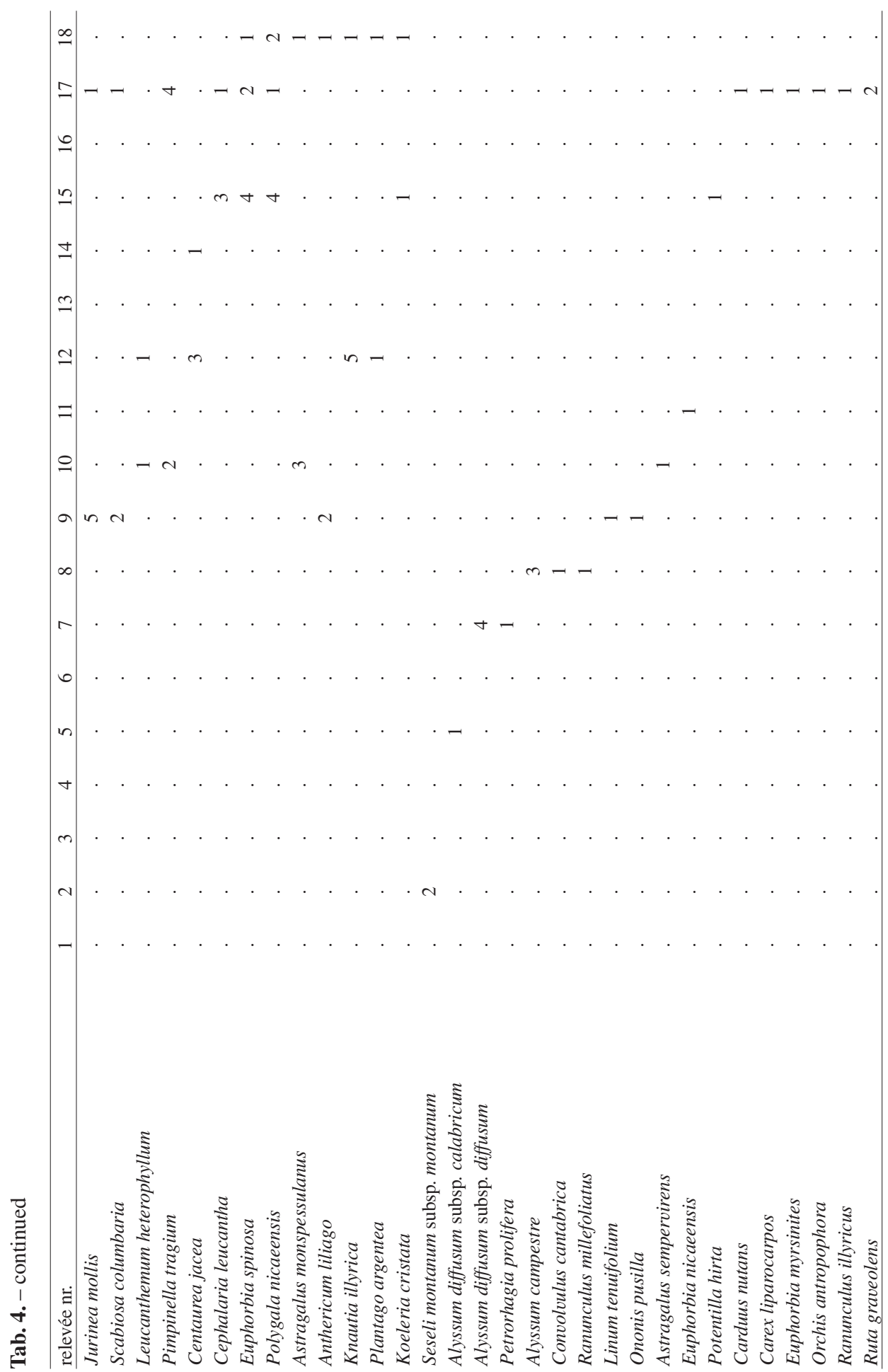


Di Pietro R., Wagensommer R. P.

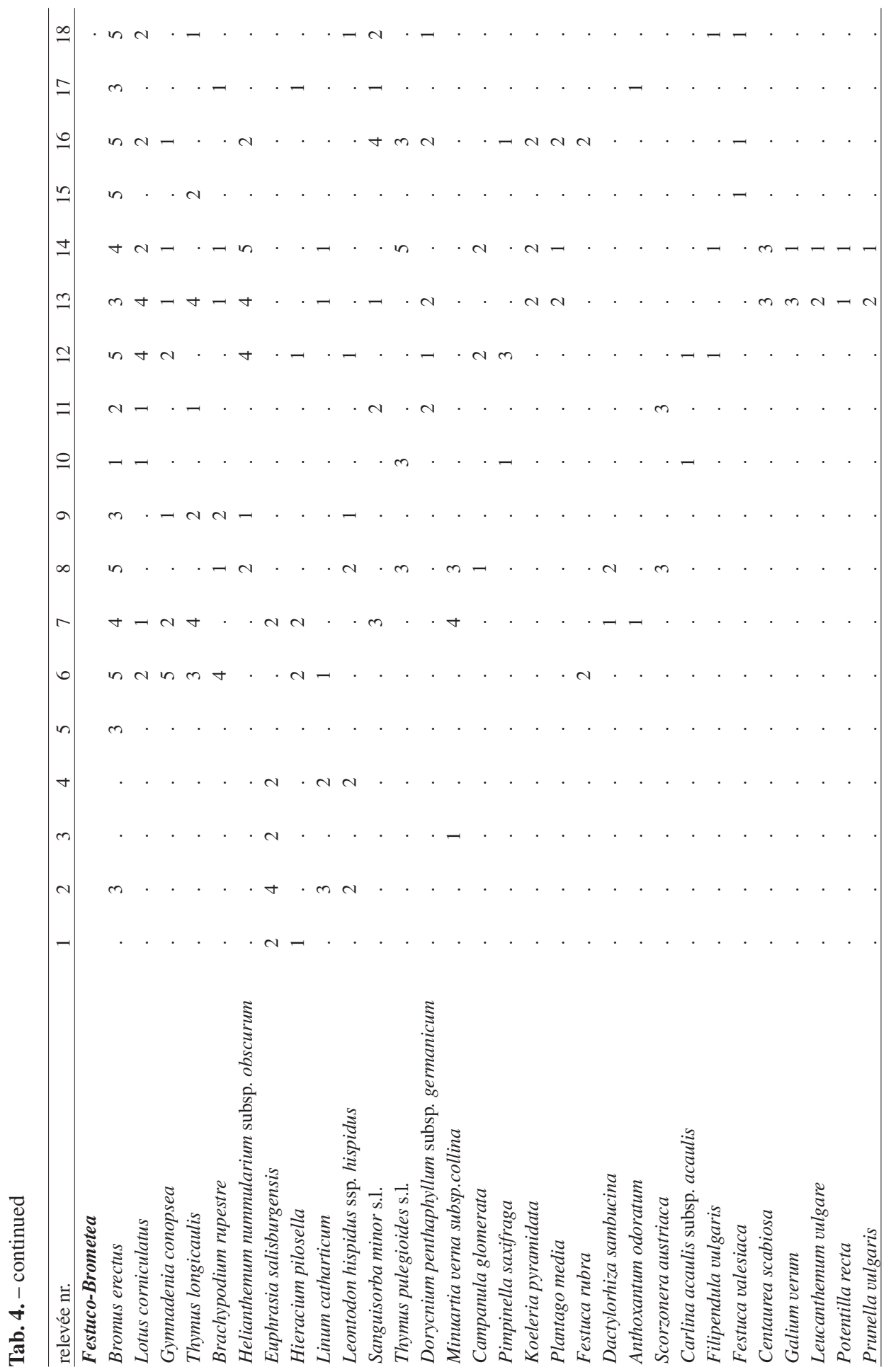

198

ACTA BOT. CROAT. 73 (1), 2014 


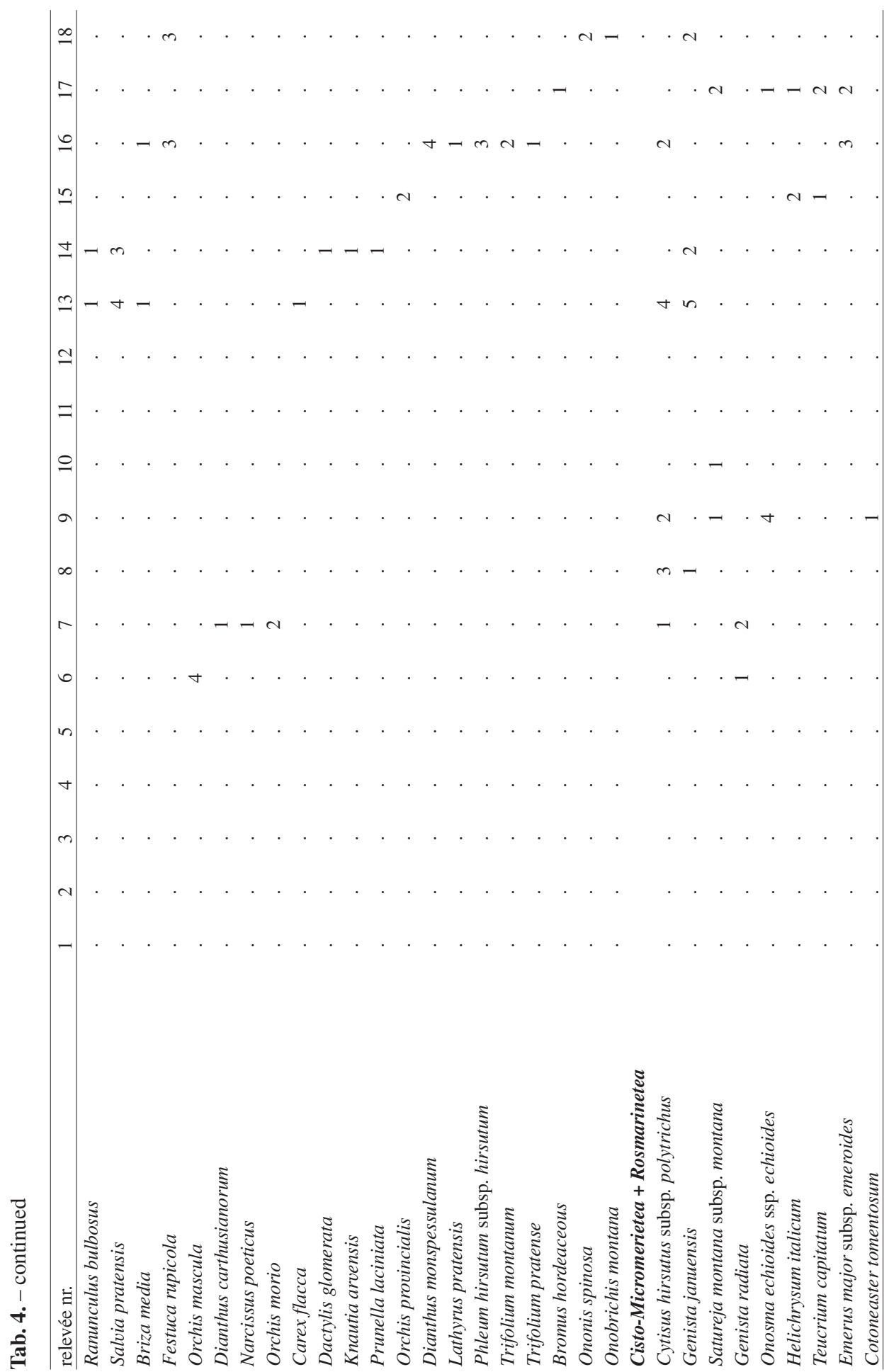


Di Pietro R., Wagensommer R. P.

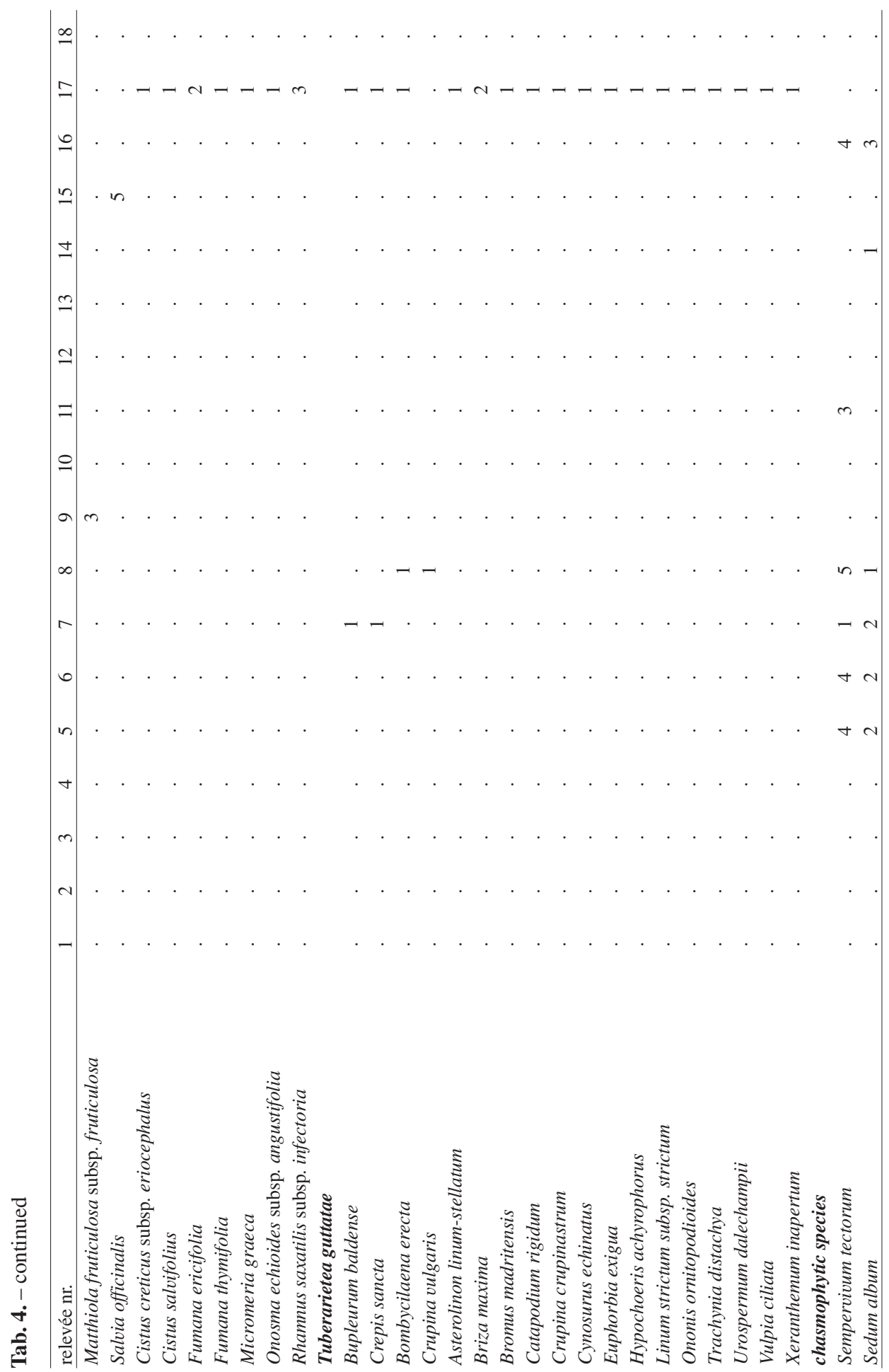




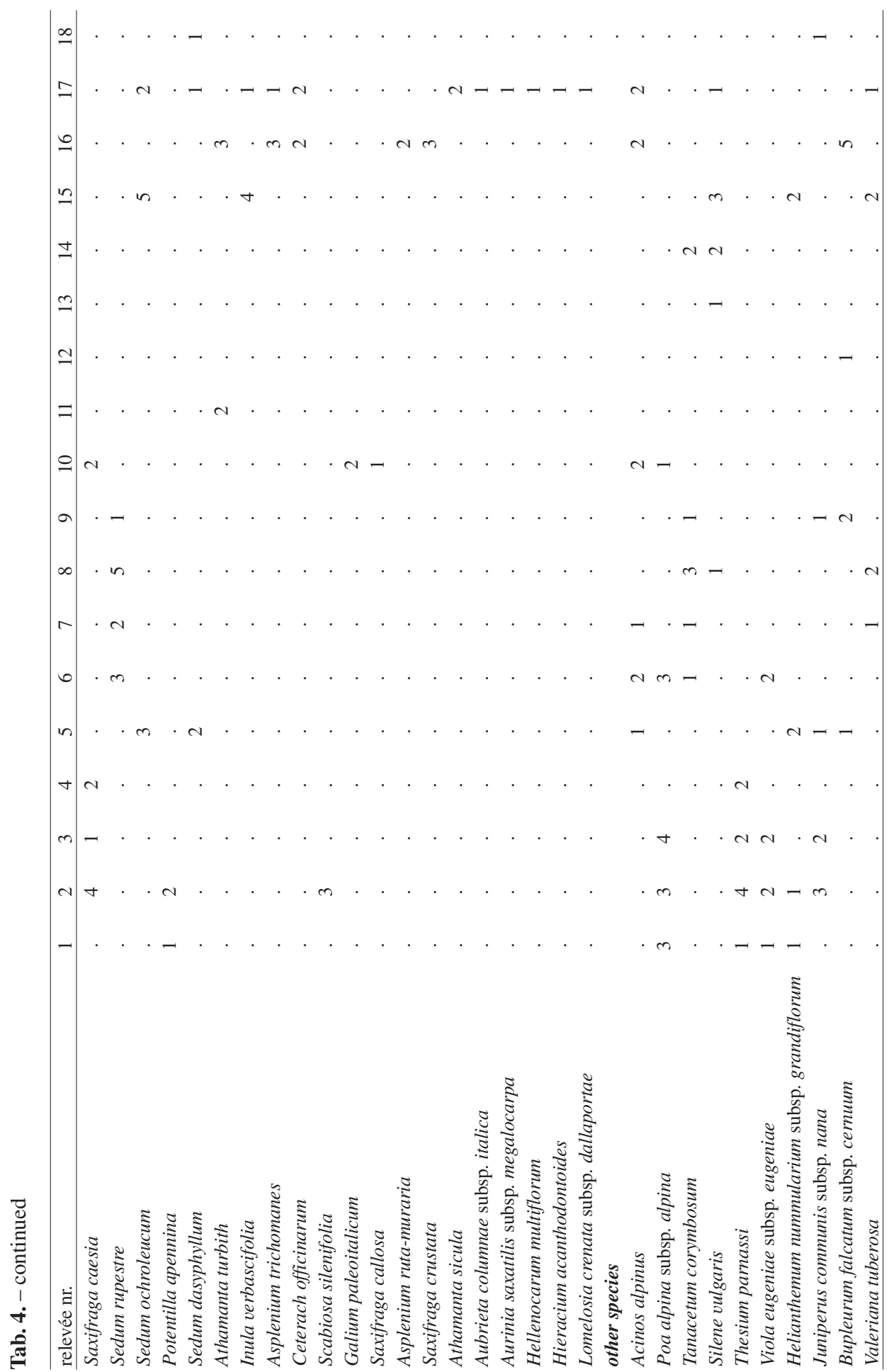


Di Pietro R., Wagensommer R. P.

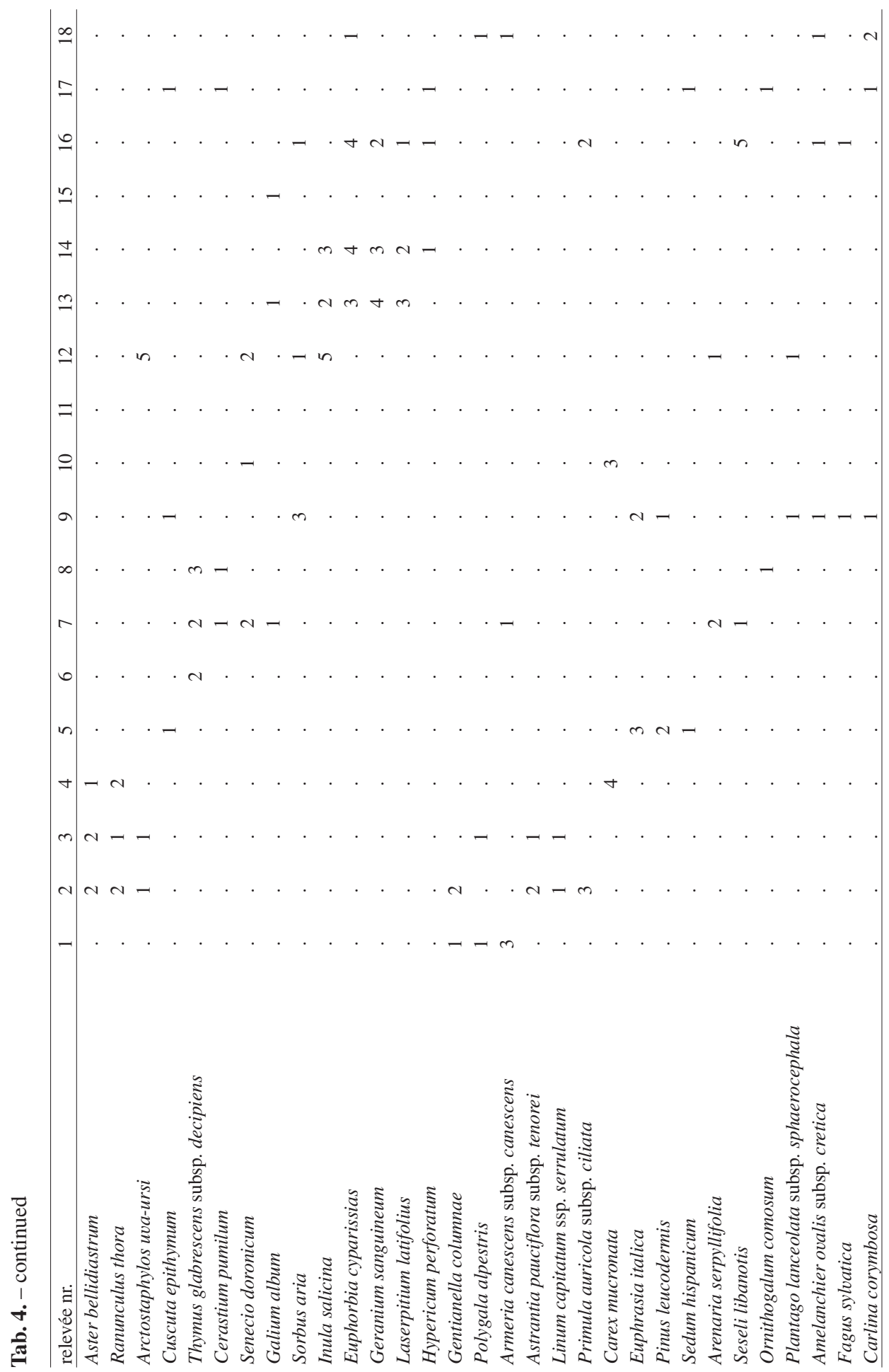




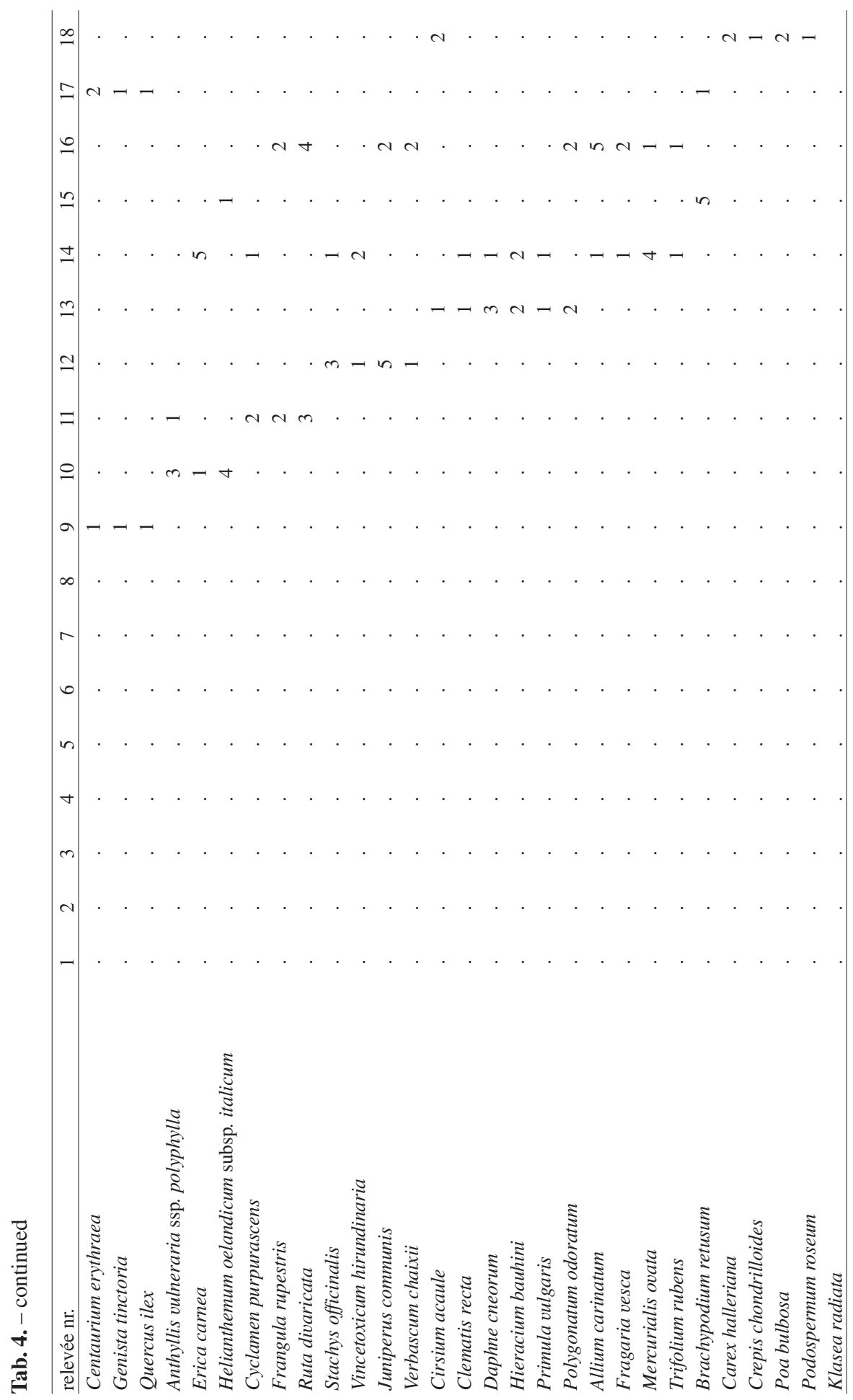


crepido-Stipion austroitalicae but its placing at higher syntaxonomical ranks remains uncertain. The lack of any pan-European synthesis on this topic makes the inclusion of Stipo-Seslerietum in Scorzonero-Chrysopogonetalia nothing but provisional. The general revision of south-European dry grasslands is currently in progress will certainly provide new elements for the solution of this syntaxonomical and biogeographical issue.

\section{Syntaxonomical scheme}

Festuco-BrometeA Br.-Bl. et Tüxen ex Br.-Bl. 1949

Scorzonero villosae-Chrysopogonetalia grylli Horvatić et Horvat in Horvatić 1963 (prov.)

Festuco circummediterraneae-Seslerienalia nitidae Di Pietro 2011

Hippocrepido glaucae-Stipion austroitalicae Forte et Terzi in Forte, Perrino et Terzi 2005 Stipo austroitaliacae-Seslerietum juncifoliae Di Pietro et Wagensommer ass. nov.

Stipo austroitaliacae-Seslerietum juncifoliae typicum subass. nov.

Stipo austroitaliacae-Seslerietum juncifoliae helianthemetosum apennini subass. nov. Stipo austroitaliacae-Seslerietum juncifoliae seslerietosum autumnalis subass. nov.

Syntaxa quoted in the text are listed in the Online supplement appendix 5.

\section{Acknowledgements}

The authors thank La Sapienza University for financial support (grant prot. C26F07X4MY - 2007). We are also grateful to all colleagues who contributed some references that were hard to obtain for this study (A. Alegro, A. Carni, M. Vidali and L. Poldini). Thanks also to the anonymous reviewers their useful suggestions and comments.

\section{References}

Alegro, A., 2007: Systematics and distribution of Sesleria juncifolia complex in the Dinaric Area (In Croatian). PhD Thesis, University of Zagreb.

Barbero, M., Bono, G., 1973: La végétation orophile des Alpes Apuanes. Vegetatio 27, $1-48$.

BAZZICHELLI, G., FURNARI, F., 1979: Ricerche sulla flora e sulla vegetazione di altitudine nel Parco Nazionale d'Abruzzo. Pubblicazioni dell' Istituto di Botanica dell'Università di Catania 1, 1-87.

Bianco, P., Brullo, S., Pignatti, E., Pignatti, S., 1988: La vegetazione delle rupi calcaree della Puglia. Braun-Blanquetia 2, 133-151.

Biondi, E., Ballelli, S., Allegrezza, M., Taffetani, F., Frattaroli, A.R., Guitan, J., Zuccarello, V., 1999: La vegetazione di Campo Imperatore (Gran Sasso d'Italia). Braun-Blanquetia 16, 33-53.

Biondi, E., Ballelli, S., Allegrezza, M., Zuccarello, V., 1995: La vegetazione dell' ordine Brometalia erecti Br.-Bl. 1936 nell' Appennino (Italia). Fitosociologia 30, 3-45. 
Biondi, E., Guitian, J., Allegrezza, M., Ballelli, S., 1988: Su alcuni pascoli a Sesleria apennina Ujhelyi nell' Appennino centrale. Documents Phytosociologiques n.s. 11, 417-422.

Biond, E., Pinzi, M., GubelLini, L., 2004: Vegetazione e paesaggio vegetale del Massiccio del Monte Cucco (Appennino centrale, Dorsale Umbro-Marchigiana). Fitosociologia $41,1-81$.

BLASI, C., 2003: Ecological information in Italy. Società Botanica Italiana e Direzione per la conservazione della Natura, Ministero dell'Ambiente e della Tutela del Territorio, Tipolitografia CSR, Roma: 1-100.

Blasi, C., Di Pietro, R., Fortini, P., Catonica, C., 2003: The main plant community types of the Alpine belt of the Apennine chain. Plant Biosystems, 137, 83-110.

Blasi, C., Di Pietro, R., Pelino, G., 2005: The vegetation and landscape of alpine belt karst-tectonic basin in the Majella mountain (central Apennines). Plant Biosystems 139, 357-385.

Braun-Blanquet, J., 1964: Pflanzensoziologie. Grundzüge der Vegetationskunde. Springer Verlag, Wien.

BriLli-CATTARINI, A. J. J., 1972: Le gole rupestri dell' Appennino marchigiano. Natura e Montagna 3, 7-16.

Bruno, F., Furnari, F., 1966: Excursion de la société internationale de phytosociologie dans les Abruzzes (Apennins centraux). Notiziario della Società Italiana di Fitosociologia 3, 1-50.

Catorci, A., Gatti, R., Ballelli, S., 2007: Studio fitosociologico della vegetazione delle praterie montane dell' Appennino maceratese (Italia centrale). Braun-Blanquetia 42, $101-143$.

Conti, F., Abbate, G., Alessandrini, A., Blasi, C. (eds.), 2005: An annotated checklist of the Italian vascular flora. Palombi Editore, Roma.

Costanzo, E., Furnari, F., Tomaselli, V., 2009: A phytosociological survey of the main plant community types of alpine and sub-alpine belt in the Sibillini Mountains (Central Apennines, Italy). Lazaroa 30, 219-250.

Dakskobler, I., Peljhan, J., 2007: Viola pyrenaica Ramond ex DC. in the northern part of the Dinaric mountains (In Slovenian). Hacquetia 6, 143-169.

DeYL, M., 1946: Study of the genus Sesleria. Opera Botanica Cechica 3, 1-246.

Deyl, M (1980) Sesleria Scop. In: Tutin, T. G., Heywood, V. H., Burges, N. A., Moore, D. M., Valentine, D. H., Walters, S. M., WebB, D. A. (eds.) Flora Europaea 5 (Alismataceae to Orchidaceae), 173-177. Cambridge University Press, Cambridge.

Di PIETRO, R., 2007: Taxonomical features of Sesleria calabrica stat. nov. (Poaceae), a neglected species from southern Italy. Folia Geobotanica 42, 289-313.

Di Pietro, R., 2010: Phytosociological features of Sesleria calabrica (Poaceae), an endemic species of Pollino-Orsomarso mountains (southern Italy). Acta Botanica Gallica 157, 539-554.

Di PiETRo, R., 2011: New dry grassland associations from Ausoni-Aurunci mountains (central Italy). Syntaxonomical updating and discussion on the higher rank syntaxa. Hacquetia $10,183-231$. 
Di Pietro, R., D’ Amato, G., Trombetta, B., 2005: Karyology and distribution of Sesleria tenuifolia complex (Poaceae) in the Italian Peninsula. Nordic Journal of Botany 23, 615-623.

Di Pietro, R., Wagensommer, R.P., 2008: Analisi fitosociologica su alcune specie rare o minacciate del Parco Nazionale del Gargano (Italia centro-meridionale) e considerazioni sintassonomiche sulle comunità casmofitiche della Puglia. Fitosociologia 45, 177-200.

EURO + MEd Plant Base, the information resource for Euro-Mediterranean plant diversity. Retrieved September 3, 2012 from http://www.emplantbase.org/information.html

FANElli, G., LuCCheSE, F., PAURA, B., 2001: Le praterie a Stipa austroitalica di due settori adriatici meridionali (basso Molise e Gargano). Fitosociologia 38, 25-36.

FENAROLI, L., 1974: Florae Garganicae Prodromus. Pars quarta. Webbia 29, 123-301.

Feoli-Chiapella, L., Poldini, L., 1993: Prati e pascoli del Friuli (NE Italia) su substrati basici. Studia Geobotanica 13, 3-140.

Forte, L., Perrino, E. V., Terzi, M., 2005: Le praterie a Stipa austroitalica Martinovsky ssp. austroitalica dell' Alta Murgia (Puglia) e della Murgia Materana (Basilicata). Fitosociologia 42, 83-103.

HoRvat, I., 1930: Study of vegetation of Croatian mountains: I. Plant communities of high mountain areas (in Croatian). Rad Jugoslavenske Akademije Znanosti i Umjetnosti 238, 1-96.

Horvat, I., Glavač, V., Ellenberg, H., 1974: Vegetation Südosteuropas. Geobotanica Selecta 4. G. Fischer, Stuttgart.

HoRvatić, S., 1973: Syntaxonomic analysis of the vegetation of dry grassland and stony meadows in Eastern Adriatic coastal Karts district based on the latest phytocoenological research. Fragmenta Herbologica Jugoslavica 32, 1-15.

HoRvatić, S., 1975: Neuer Beitrag zur Kenntnis der Syntaxonomie der Trocken-Rasen und Steintriften-Gesellschaften des ostadriatischen Karstgebietes. In: Jordanov, D., BoNdev, I., Kozuharov, S., Kuzmanov, B., Palamarev, E., Velcev, V. (eds.), Problems of Balkan flora and vegetation, 300-310. Bulgarian Academy of Sciences, Sofia.

IUCN, 2006: Guidelines for using the IUCN Red List categories and criteria. Version 6.2. Standards and Petitions Working Group of the IUCN SSC Biodiversity Assessments Subcommittee.

KALIGARIČ, M., 1994: Association Genisto sericeae - Seslerietum juncifoliae Poldini in Slovenia (in Slovenian). Anali za Istarske in Mediteranske Študije 4, 83-86.

LAKUŠIĆ, D., KARADŽIĆ, B., 2010: New associations of serpentine chasmophitic vegetation (Asplenietea trichomanis Br.-B1. 1934 corr. oberd. 1977) on Kopaonik Mt in Serbia. Botanica Serbica 34, 67-79.

Licht, W., 2008: Bestimmungschlüssel zur Flora des Gargano (Süd-Italien). Shaker Verlag, Aachen.

Mucina, L., Dengler, J., Bergmeier, E., Čarni, A., Dimopoulos, P., Jahn, R., Matevski, V., 2009: New and validated high-rank syntaxa from Europe. Lazaroa 30, 267-276.

Noest, V., Van der MaArel, E., Van der Meulten, F., Van der Loan, D., 1989: Optimum-trasformation of plant species cover abundance values. Vegetatio 83, 167-178. 
Petriccione, B., Persia, G., 1995: Prodromo delle praterie di altitudine degli Appennini su calcare (classe Festuco-Seslerietea). Atti dei convegni lincei, Accademia Nazionale dei Lincei (Roma) 115, 361-389.

PignATTI, S., 1982: Flora d'Italia. Edagricole, Bologna.

PODANI, J., 2001: SYN-TAX 2000. Computer programs for data analysis in ecology and systematics. User's manual. Scientia Publishing, Budapest, Hungary.

PoldiNI, L., 1980: Übersicht über die Vegetation des Karstes von Triest und Görz (NO Italien). Studia Geobotanica 1, 79-130.

ReDžIć, S., 1999: The syntaxonomic differentiation of the Festuco-Brometea Br.-Bl. \& R. Tx. 1943 ex Klika et Hadač 1944 in the Balkans. Annali di Botanica (Roma) 57, 167-180.

ROYER, J. M., 1991: Synthèse eurosibérienne, phytosociologique et phytogéographique de la classe des Festuco-Brometea. Dissertationes Botanicae 178, 1-296.

Strgar, V., 1981: Die Sippenstruktur von Sesleria auf der Balkanhalbinsel. Botanische Jahrbücher für Systematik, Pflanzengeschichte und Pflanzengeographie 102, 215-224.

Sugar, I., 1972: Plant life of Samoborsko Gorje (In Croatian). PhD Thesis, University of Zagreb.

Terzi, M., D’Amico, F. S., 2008: Chasmophytic vegetation of the class Asplenietea trichomanis in south-eastern Italy. Acta Botanica Croatica 67, 147-174.

Terzi, M., Di Pietro, R., D’ Amico, F. S., 2010: Analisi delle specie indicatrici applicata alle comunità a Stipa austroitalica Martinovsky e relative problematiche sintaxonomiche. Fitosociologia 47, 3-28.

TRINAJSTIĆ, I., 1969: Das Bromo-Seslerietum interruptae Trinajstic 1965 eine mediterran-montane bis subalpine uebergangsgesellschaft des ostadriatischen kuestenlandes). Mitteilungen der Ostalpin-Dinarischen Pflanzensoziologische Arbeitsgemeinschaft 9, 145151.

TRINAJSTIĆ, I., 1977: Overview of the vegetation of the Island of Hvar and its phytogeographical position in the European part of Mediterranean Basin (In Croatian). Poljoprivreda i Sumarstvo 23, 1-36.

TRINAJSTIĆ, I., 1987: Syntaxonomic revision of plant communities in the mountains of Biokovo (In Croatian). Acta Biokovica 4, 143-174.

UbALDI, D., 2006: Contributo alla tassonomia di Sesleria apennina Ujhelyi. Quaderno di studi e notizie di storia naturale della Romagna 22, 65-74.

UJHELYI, J., 1959: Revision des especies du genre »Sesleria en Italie. Webbia 14, 597-614.

VAN DER MAAREL, E., 1979: Transformation of cover-abundance values in phytosociology and its effects on community similarity. Vegetatio 39, 97-114.

WAGENSOMMER, R. P., 2010: Applicazione critica dei criteri IUCN ad alcune specie rare e rappresentative della flora del Gargano (Italia centro-meridionale). PhD Thesis, University of Florence.

Wagensommer, R. P., Di Pietro, R., 2006: Notulae alla Checklist della Flora Italiana 1244-1245. Informatore Botanico Italiano 38, 205-206.

Weber, H. E., MoraVec, J., Theurillat, J. P., 2000: International code of phytosociological nomenclature. Journal of Vegetation Science 11, 739-768. 